\title{
Direitos Humanos no Brasil: Limites e Possibilidades para a Eficácia das Sentenças Prolatadas pela CIDH
}

\author{
Ana Paula Adam \\ Acadêmica do Curso de Direito da Universidade do Vale \\ do Rio dos Sinos. Estagiária no Ministério Público de \\ São Sebastião do Caí/RS. Bolsista de iniciação científica \\ (Pratic). Pesquisadora. anapaula.adam@gmail.com
}

\section{Débora Bós e Silva}

Graduada em Direito pela Universidade do Vale do Rio dos Sinos (Unisinos). Juíza Leiga. Recém-aprovada no X Exame de Ordem. Bolsista de Iniciação Científica (Unibic e Fapergs), durante o período de 2010-2012, nos projetos: "Processo e Constituição: A construção das funções democráticas de acesso à justiça", e "0 processo civil visto pela teoria do Estado Democrático de Direito e pela Constituição: aportes monista e hermenêutico na criação dos direitos fundamentais a partir da primazia do caso concreto", na linha de pesquisa Hermenêutica, Constituição e Concretização de Direitos, do Programa de Pós-Graduação em Direito na Unisinos, tendo como orientador o prof. Dr. Darci Guimarães Ribeiro. Pesquisadora nas áreas de: Direito Processual Civil, Direitos Humanos, Direito Internacional, Direito Constitucional e Antropologia. Monitora de disciplinas de cursos preparatórios para a Magistratura Federal e Ministério Público Federal.debbie-bos@hotmail.com

\section{Paola Leonetti}

Acadêmica do curso de Direito da Universidade do Vale do Rio dos Sinos. Bolsista de iniciação científica. Pesquisadora. Iolitabest@ig.com.br 


\title{
Resumo
}

0 presente artigo aborda a temática relativa aos limites e possibilidades para a eficácia das sentenças prolatadas pela Corte Interamericana de Direitos Humanos em âmbito brasileiro, tendo em vista a sua dificuldade de concretização plena. 0 objetivo deste trabalho reside em apresentar soluções para um problema de longa data, a partir da análise dos casos envolvendo o Brasil, e as contribuições expressivas trazidas pelo Direito Comparado. Considerando o problema enfrentado, foi utilizado o método fenomenológico-hermenêutico, pois o objeto de estudo faz parte do mundo social e os resultados obtidos na pesquisa visam a atribuir sentido e importância às presentes e futuras ações de efetividade das sentenças. Daí a importância de um estudo dirigido de forma crítica e interpretativa sob esse método introduzido por Martin Heidegger e aprofundado por Hans-Georg Gadamer. 0 ponto de partida apresentado por Heidegger mostra sua pertinência no decorrer da pesquisa, tendo em vista a referência histórica dada à evolução dos direitos humanos no Brasil e no mundo (Stein, 1979). Foram feitos estudos de casos, método comparativo entre eles, pesquisa bibliográfica nacional e estrangeira e pesquisa jurisprudencial. Como principais resultados da pesquisa elaborada, o Brasil peca na falta de responsabilização dos culpados, mas, cumprindo com a prestação de valores pecuniários exigidos, e com a instituição (ainda que insuficiente) das medidas solicitadas. É necessário que os direitos humanos se convertam, realmente, em uma política de Estado, e não meramente em um "discurso" a ser levantado pelas bandeiras políticas dos países sem aplicabilidade prática.

Palavras-chave: Corte Interamericana. Direitos humanos. Sentenças. Limites. Possibilidades.

\section{Human Rights in Brazil: Limits and Possibilities for the Effectiveness Judgments of the CIDH}

\begin{abstract}
:
This article discusses the issue concerning the limits and possibilities for the effectiveness of judgments issued by the Inter-American Coutr of Human Rights at Brazil, with a view to full implementation of its difficulty. The objective of this work is to provide solutions to a longstanding problem, from na analysis of cases involving Brazil, and the significant contribuions brought by comparative law. Considering the problem faced was used hermeneutic phenomenological method, therefore the object of study is parto $f$ the social world and the results obtained in the investigation to confer meaning and importance to presente and future actions effectiveness of sentences. Therefore, the importance of a study conducted in a critical and interpretive under this method introduced by Martin Heidegger and deepened by Hans-Gerog Gadamer. The starting point presented by Heidegger shows their relevance in the discourse of research, in view of the historical reference given to the evolution of human rights in Brazil and in the world (Stein, 1979). We made case studies, including comparative method, literature and foreign and jurisprudential research. The main results of the research carried out, Brazil piece on the lack of accountability of perpetrators, but complying with the provision of monies required, and the implementation (albeit insuficiente) of the relief sought. It is necessary that human rights should be converted, really, in a state policy, and not merely in a 'discourse' to be raised by the flags of the countries policies without practical applicability.
\end{abstract}

Keywords: Interamerican Court. Human rights. Senteces. Limits. Possibilities. 


\section{Sumário}

1 Introdução. 2 Direitos Humanos no Brasil. 2.1 Cenário atual brasileiro ao que tange os Direitos Humanos. 2.2 Como o STF tem decidido sobre os Direitos Humanos no Brasil. 30 Sistema Regional Interamericano de Direitos Humanos na Democracia Contemporânea. 3.1 Origem, conceito, função e composição da Corte Interamericana de Direitos Humanos. 3.2 Casos brasileiros submetidos a Corte Interamericana de Direitos Humanos. 3.2.1 Caso 1 (Guerrilha do Araguaia x Brasil). 3.2.2 Caso 2 (Damião Ximenes Lopes x Brasil). 3.2.3 Caso 3 (Nogueira de Carvalho x Brasil). 3.2.4 Caso 4 (Escher e outros x Brasil). 3.2.5 Caso 5 (Sétimo Garibaldi x Brasil). 3.3 0 futuro do Sistema Interamericano de Direitos Humanos e a democracia. 4 Limites e Possibilidades Para a Eficácia das Sentenças Prolatadas Pela Corte Interamericana de Direitos Humanos. 4.1 Eficácia interna das sentenças prolatadas pela CIDH envolvendo o Brasil. 4.2 Limites que impedem a eficácia plena no plano interno das sentenças prolatadas pela Corte Interamericana de Direitos Humanos. 4.3 Execução das sentenças de Direitos Humanos no direito comparado. 4.4 Possibilidades para o avanço da eficácia das decisões no Brasil. 5 Conclusão. 6 Referências 


\section{INTRODUÇÃO}

Desde a proclamação dos princípios universais básicos de liberdade, igualdade e fraternidade, os direitos humanos passaram a ser reconhecidos no cotidiano como direitos de todos, exigindo-se a efetivação dos princípios contidos em documentos jurídicos da mais alta estirpe para a consolidação da democracia e a valorização da dignidade humana. Muito se tem discutido recentemente acerca da falta de meios coercitivos para que o Estado execute uma decisão da Corte Interamericana de Direitos Humanos (CIDH). Tal inquietação se constitui em uma preocupação em âmbito global, uma vez que limita, e até mesmo impede de forma plena a efetivação dos direitos humanos.

Esse descaso com o não cumprimento das sentenças, por parte do Estado brasileiro é o que nos impulsiona avidamente a buscar respostas e propostas que se inclinem para a construção de mecanismos de responsabilização coercitivos.

Para que isso seja possível é imperioso pesquisar qual é o cenário atual acerca dos direitos humanos no Brasil, suas bravuras e mazelas, bem como sua postura diante das recentes decisões da CIDH condenando o Brasil por violações de direitos humanos, além de propor soluções para um problema de longa data, inclusive em âmbito internacional, haja vista que tal postura coloca em risco o futuro da democracia.

\section{DIREITOS HUMANOS NO BRASIL}

\subsection{Cenário atual brasileiro no que se refere aos direitos humanos}

Quando procuramos discorrer acerca do cenário atual dos direitos humanos, nossos olhos voltam-se para a realidade brasileira cotidiana: a violação constante do direito à alimentação, o desrespeito pelas garantias 
judiciais do amplo acesso à Justiça, a violação da dignidade da pessoa humana, a violência contra a mulher, e por que não citar a violação dos direitos das crianças, adolescentes e dos idosos, considerados estes como grupos minoritários aos quais a defesa se torna imprescindível?

Bem-vindos ao panorama atual brasileiro, com suas mazelas e virtudes, em que apesar dos problemas existentes vem ocorrendo um contínuo esforço e mobilização em prol do resgate dos direitos humanos.

Essa mobilização demonstra a conscientização dos próprios direitos e do reconhecimento por parte dos cidadãos dos direitos dos seus semelhantes, o que em nosso entendimento, constitui-se no auge de uma consciência coletiva superior, que permite que o indivíduo reconheça o outro como sujeito de direitos, apesar das sensíveis diferenças que os separam.

Há uma dupla face no cenário atual brasileiro ao que tange os direitos humanos, pois, se de um lado existem diversos direitos humanos reclamando atenção, de outro existe comprometimento para reconhecer e buscar formas de pôr em prática tais direitos. ${ }^{1}$

Nesse cenário, é indispensável a promoção, por parte dos Estados, do acesso às garantias que proporcionem a materialidade da efetivação dos direitos fundamentais. O Brasil enfrenta uma série de dificuldades quanto ao andamento dos processos judiciais.

A demanda excessiva dos pedidos de resolução de litígios, falta de estrutura adequada para os servidores públicos exercerem suas funções e dificuldade na inserção de novos profissionais capacitados para exercerem

${ }^{1}$ Apesar de terem sido apresentadas progressivas melhoras, o problema ainda persiste, pela falta de políticas públicas concretizáveis e pela falta de incentivo à agricultura familiar. 
essa atividade podem ser apontados como alguns dos diversos fatores que levam à problemática existente no Brasil, que é a dificuldade de acesso à Justiça. ${ }^{2}$

De outra banda, um dos problemas que mais afligem o Brasil envolve a superlotação carcerária, não possibilitando a recuperação social como pessoa humana, eis que as consequências trazidas pelo cárcere brasileiro são das mais macabras possíveis, como pode ser constatado pelo Presídio Central, localizado em Porto Alegre/RS, considerado a pior casa prisional brasileira.

Por meio de laudos técnicos ${ }^{3}$ que atestaram a necessidade de uma intervenção urgente, foi considerado irrecuperável, apresentando graves riscos à saúde das pessoas e ao meio ambiente. Nesse cenário sub-humano - e porque não dizer, desumano -, já virou rotina a contaminação de verminoses em decorrência das péssimas condições do local, com esgoto a céu aberto, a ausência de condições mínimas de higiene, a companhia dos “amigos” roedores já virou uma constante, e a ressocialização prisional já se transformou em um sonho muito distante para muitos.

${ }^{2}$ Segundo dados levantados pelo Conselho Nacional de Justiça, em 2010 tramitavam cerca de 84 milhões de processos no Judiciário. Um exemplo de como é dificultoso o acesso à Justiça no Brasil pode ser visto, pelo caso Simone André Diniz, denunciado na Comissão Interamericana de Direitos Humanos, em que a vítima não foi aceita em um trabalho de doméstica por ser negra. O caso ocorreu em 1997, em São Paulo, e o processo foi arquivado pelo Ministério Público que investigava o caso, por se ter entendido que não houve racismo e violação aos direitos fundamentais. O Brasil foi condenado em 2006 em razão de ter permitido o arquivamento de um processo de discriminação racial, violando portanto os artigos da Convenção Americana de Direitos Humanos e da Convenção Racial.

${ }^{3}$ Com o objetivo de verificar a situação atual da estrutura prisional, foram elaborados três laudos técnicos no final de abril, por parte do Conselho Regional de Engenharia, Arquitetura e Agronomia do Rio Grande do Sul (Crea/RS), que concluíram que a situação estrutural do Presídio Central chegou ao seu limite máximo, de tal forma que, por apresentar grau de risco crítico é irrecuperável, e qualquer reforma - tal como a que acabou de ser feita na cozinha prisional -, seria antieconômica, por representar um valor financeiro muito elevado para a sua recuperação total. 
Diante desse cenário desolador, a Associação dos Juízes do Rio Grande do Sul cobrou ações do governo do Estado, e diante da percepção de que nada foi feito ao longo dos tempos, decidiu ingressar com uma denúncia perante a Comissão Interamericana de Direitos Humanos, por entender que os juízes também são responsáveis eticamente por aqueles que prendem, tendo agora o dever de reverter essa situação, como bem enfatizou o presidente da Ajuris, Pio Giovani Dresch.

Ainda em relação aos direitos humanos mais fragilizados, importa mencionar que o Brasil, apesar de abrigar a maior associação de Gays, Lésbicas, Bissexuais, Transexuais, Travestis e Transgêneros (GLBT) da América Latina, é, também, líder mundial de mortes contra essa população, conforme Luiz Mott (Mott, 2012).

Mantendo um olhar atento ao que vem ocorrendo no Brasil, a CIDH condenou o deplorável assassinato de um adolescente que se autointitulava homossexual assim como o assassinato de duas mulheres transexuais, nos Estados do Paraná e São Paulo. Ao se manifestar sobre os casos, a CIDH afirmou:

A CIDH urge ao Estado a adotar ações para evitar e reagir a esses abusos aos direitos humanos e garantir que as pessoas LGTBI possam exercer efetivamente seu direito a uma vida livre de discriminação e violência, incluindo a adoção de políticas e campanhas públicas, assim como as reformas necessárias para adequar as leis aos instrumentos interamericanos em matéria de direitos humanos. 4

Na prática, o número de homossexuais assassinados no Brasil superou mais de 250 casos em 2010, ultrapassando o México (35 casos por ano) e os Estados Unidos (25 casos por ano), refletindo em uma escalada gradual de violência em crimes de ódio por haver uma impunidade muito

${ }^{4}$ Comunicado de imprensa: Disponível em: <http://cidh.oas.org/Comunicados/ Port/2012.89.html>. Acesso em: 10 jun. 2012. 
grande no país. Só no primeiro semestre de 2012 foram assassinados 165 homossexuais, sendo São Paulo, Paraíba e Bahia os Estados mais perigosos e homofóbicos. Esses dados são muito preocupantes, demonstrando que a homofobia é muito grande em nosso país, apesar de terem sido feitas incursões em prol de ações afirmativas, por meio do "Programa Brasil sem Homofobia”, pois a população continua com um alto índice de intolerância que se reflete por meio de homicídios. Enfatiza-se, portanto, que em razão desse ódio cultural, os casos de discriminação e violência estão se tornando cada vez mais gritantes, em pleno século 21.

Além das situações anteriormente apresentadas, importa nos debruçarmos sobre a exploração do trabalho infantil doméstico, dada a gravidade de tal tema, e, também, pelo fato de o Brasil ser considerado o terceiro país da América Latina que mais explora o trabalho infantil, atrás somente do Haiti e da Nicarágua, revelando-se este um acontecimento que deve ser modificado. ${ }^{5} \mathrm{Na}$ concepção de Celso de Mello, a tortura cometida contra crianças, nos mais diversos níveis de exploração, se constitui na negação arbitrária dos direitos humanos, pois reflete - enquanto prática ilegítima, imoral e abusiva -, um inaceitável ensaio de atuação estatal tendente a asfixiar e, até mesmo, a suprimir a dignidade, a autonomia e a liberdade com que o indivíduo foi dotado, de maneira indisponível, pelo ordenamento positivo.

Por fim, mas não menos importante, é necessário mencionar a violência contra a mulher, considerado um dos problemas mais graves no Brasil. Esse problema desponta como um dos mais preocupantes, seja pelo número alarmante de casos, alçando o Brasil ao posto de campeão em violência doméstica em um ranking de 54 países, como também pelo crescimento expressivo dessa modalidade de violência, o que por si só representa um atentado aos direitos humanos.

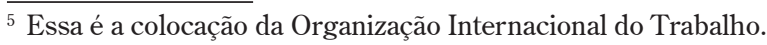


A Convenção Interamericana para prevenir, punir e erradicar a violência contra a mulher representa o esforço para dar visibilidade à existência desse problema e exigir seu repúdio pelos Estados-Membros da Organização dos Estados Americanos (OEA).

Conforme Baersted, quando a participação da vítima é analisada à luz da perspectiva de gênero, pode ser visto que a cultura delega a homens e mulheres diferentes padrões de moralidade e de valores. Assim, quando a mulher tem uma vida autônoma de seu marido, ou seja, trabalha fora, tem horários próprios, etc., isto é entendido como sendo um comportamento preparatório a um possível crime de adultério (Nerba; Grossi, 2001).

Hoje já é possível denunciar casos envolvendo violência doméstica perante a Comissão Interamericana de Direitos Humanos. Tanto é verdade que a Lei Maria da Penha só foi criada após a condenação do Brasil perante a Comissão, por negligência e omissão em relação à violência doméstica. ${ }^{6}$

${ }^{6}$ Esse caso teve um grande significado para o Brasil, pois, apesar de ter ido somente até a Comissão Interamericana de Direitos Humanos, foi crucial para que o Brasil editasse uma lei protetiva em defesa das mulheres vítimas de violência doméstica. O caso Maria da Penha teve início em 1983, quando a farmacêutica Maria da Penha Maia Fernandes sofreu a primeira agressão grave de seu marido, o professor universitário Marco Antônio Herredia Viveiros. Ele havia disparado um tiro contra ela enquanto estava dormindo e alegou terem sido bandidos que haviam invadido a casa do casal. Do disparo restou uma sequela para Maria da Penha: ela ficou paraplégica. Na segunda agressão, Marco Antônio tentou eletrocutá-la no chuveiro. Maria da Penha denunciou o caso à polícia, mas só no ano seguinte o caso chegou ao Ministério Público. Dentre todos os trâmites judiciais, o advogado de Marco Antônio conseguiu anular o processo. Numa segunda tentativa de Maria, seu agressor foi preso (passados 15 anos), porém permaneceu apenas dois anos na prisão. Maria da Penha não teve dúvida, e entrou com uma ação perante a Comissão Interamericana de Direitos Humanos. Foi a primeira denúncia de violência doméstica acatada pela Comissão. A partir de então, o Estado brasileiro se viu obrigado a agir de maneira diferente da que vinha agindo. Dentre as recomendações mais importantes da Comissão nesse caso, foi a criação de uma legislação que que prevenisse esse tipo de violência, assim como que condenasse os agressores. Foi então, em 2006, que entrou em vigor a Lei $n^{0} 11.304$, que tira o crime praticado contra a mulher do patamar visto como irrelevante, tanto a violência física e sexual quanto a psicológica. 
Pela primeira vez na História a Comissão Interamericana aceitou uma denúncia envolvendo a violência contra a mulher, servindo de precedente para outras tantas situações que ocorrem na América Latina.

Evidentemente que a criação da lei por si só não é capaz de torná-la eficaz, então, não sejamos ingênuos em esperar que isso baste para cessar as violências e mortes cotidianas de mulheres, perpetradas, em geral, pelos seus companheiros.

Não se pode tolerar a dependência física, emocional e mental a que alguns desejam sujeitar as mulheres, uma vez que por trás da realidade feminina marcada pelos traços da opressão existe uma identidade a ser desvendada. Algo é preciso mudar, para que chegue o dia em que não mais existirão mulheres violentadas e assim se consolide uma sociedade permeada pelo equilíbrio e pela paz que tanto almejamos (Gregori, 1993).

Para que esse desafio seja possível, igualmente, é necessário haver homens comprometidos em acabar com conceitos de dominação, e isto é uma oportunidade para criar um mundo inteligente e generoso o suficiente para reconhecer a capacidade da mulher, possibilitando que possa render os melhores frutos, formando indivíduos verdadeiramente comprometidos com uma convivência mais amistosa.

\subsection{Como o STF tem decidido sobre os direitos humanos no Brasil}

A República Federativa do Brasil sempre se destacou no plano internacional como defensor dos direitos humanos, sendo um dos signatários originais da Declaração Americana de Direitos e Deveres do Homem e da Declaração Universal de Direitos Humanos. Após a Segunda Guerra Mundial, o Estado brasileiro participou de uma gama de acordos de proteção dos direitos individuais, dentre eles a Convenção sobre Genocídio de 1948 e o Pacto Internacional sobre Direitos Civis e Políticos. 
No plano interno brasileiro os direitos humanos são constitucionalizados com referência em seu preâmbulo, visto que o Estado Democrático destina-se a assegurar o exercício dos direitos sociais e individuais, prescrevendo, no inciso II do artigo $4^{\circ}$, a prevalência dos direitos humanos como princípio norteador da conduta do nosso país.

Podemos destacar, nesse passo, a argumentação de Wilson Engelmann:

Os Direitos Humanos no séc. XXI representam o resultado histórico de lutas e conquistas que os humanos vêm desenvolvendo ao longo de sua trajetória. As pessoas "civilizadas" de hoje encontram-se vinculadas a essa caminhada, sendo o seu produto ideológico. $\mathrm{Na}$ análise da afirmação da pessoa como destinatária de algumas normas e prerrogativas, chamadas de direitos humanos, é possível constatar que todas são os resultados de lutas e, especialmente, muito sofrimento. Não há nenhuma possibilidade de retorno para minorar esses sofrimentos e mortes em nome dos quais posteriormente se criaram normas para evitá-las (2009, p. 6.309).

O Brasil, diante de suas desigualdades sociais, econômicas e culturais, e ainda escudado por um posicionamento conservador por parte de seus cidadãos, reagiu lentamente às decisões envolvendo direitos humanos, prolatadas pela Corte Superior brasileira. A partir de 2004 o instrumento então denominado Amicus Curiae (amigo da Corte) passou a ter uma importância muito mais forte em nosso sistema judicial, tendo como objetivo primordial influenciar as decisões do Supremo Tribunal Federal em relação a temas de direitos humanos, por meio de pareceres em casos de grande repercussão pública e política, permitindo intervenção assistencial por parte de entidades que tenham representatividade adequada para se manifestar sobre questão pertinente à controvérsia constitucional.

A influência desse mecanismo pode ser medida pelos recentes julgamentos, e pelas conclusões da advogada Damares Medina em sua tese de Mestrado intitulada Amigo da Corte ou Amigo da Parte? Amicus 
Curiae no Supremo Tribunal Federal, evidenciando que nas ações julgadas procedentes a proporção de casos com assistência do amicus é 18\% maior do que os casos sem assistência: "Os resultados dos julgamentos do STF no período de 1992 a 2008 estabelecem uma robusta relação causal entre o ingresso do Amicus Curiae e o aumento das chances de êxito do lado por ele apoiado” (Medina, 2008). Por ocasião do aniversário de 60 anos da assinatura da Declaração Universal dos Direitos Humanos, em meados de 2008, o Brasil passou a registrar progressos fundamentais para o desenrolar de uma jurisdição constitucional protetiva.

Nesse sentido, é exemplo desse crescimento sucessivo a defesa pelo STF da não prisão do depositário infiel, por entender que, além do direito à vida - o mais fundamental de todos os direitos, por ser dele que decorrem todos os outros -, a liberdade constitui o âmago do ser humano, isto é, a natureza do indivíduo, que só pode ser restringida em casos extraordinários.

Essa posição do STF vai ao encontro da manifestação do ministro Carlos Alberto Menezes Direito (in memoriam), para quem: "Há uma força teórica para legitimar-se como fonte protetora dos direitos humanos, inspirada na ética, de convivência entre os Estados com respeito aos direitos humanos" ${ }^{7}$

O Supremo Tribunal Federal, consciente de seu papel de velar pelos direitos fundamentais assegurados pela Magna Carta, passou a adotar uma postura proativa e dinâmica, posicionando-se com maior clareza, justiça e discernimento em casos polêmicos brasileiros como o aborto voluntário

${ }^{7}$ Manifestação de voto do ministro Carlos Alberto Direito no Recurso Extraordinário 349703, quando, por unanimidade, foi negado provimento ao Recurso Extraordinário 466343, em que se discutia a prisão civil de alienante fiduciário infiel. 
em caso de gestação de feto anencéfalo ${ }^{8}$ e, ainda, no caso emblemático envolvendo o reconhecimento da união estável entre casais homoafetivos.

O que esses casos têm em comum? O simples fato de envolverem direitos humanos, assegurados tanto na Constituição Federal quanto na Convenção Americana de Direitos Humanos (Pacto de San José da Costa Rica), entre os quais o direito à proteção da honra e da dignidade, bem como da igualdade perante a lei.

Essas decisões demonstram que o STF vem atuando na defesa dos direitos humanos ao proferir decisões respaldadas em tratados, convenções e declarações assinados pelo Brasil, entre os quais o Pacto de San José da Costa Rica.

Há que se ressaltar que o Movimento Nacional de Direitos Humanos vem adotando uma postura a favor da manifestação defensora dos direitos humanos, proclamada pelos constantes avanços do STF, como passos importantes para a consolidação da democracia brasileira, que cada vez mais incentivam, de forma incisiva, os setores conservadores a respeitarem os direitos humanos. ${ }^{9}$

${ }^{8}$ Ao decidir, por exemplo, que a mulher tem o direito de interromper a gravidez em caso de gestação de feto anencéfalo, o STF deu um recado para a sociedade, no sentido de que a interrupção da gravidez nesses casos passa a ser legalizada, visto que viola a dignidade humana da mulher, se equivalendo à tortura ao obrigar que seja submetida a uma gravidez cujo feto não possui condições de sobrevivência.

${ }^{9}$ O Movimento Nacional de Direitos Humanos (MNDH) engloba a sociedade civil, não possui fins lucrativos e encontra-se presente em grande parte do território brasileiro, tendo como missão promover os direitos humanos. A amplitude de tal movimento pode ser percebida pelas campanhas desenvolvidas, quando se constata que esse movimento possui uma influência muito grande nas causas envolvendo os direitos humanos no Brasil, como pode ser visto na campanha nacional contra a pena de morte. Não obstante, os estudos e pesquisas em diversas áreas, como a violência contra a mulher, a atuação nas mobilizações em prol de uma nova Constituição em 
Essa evolução no pensamento jurídico do STF reflete-se pelo aperfeiçoamento da jurisprudência, encaminhando-se no sentido de adequar o Direito às situações cotidianas em uma sociedade em permanente transformação. O novo papel desempenhado pela Corte Superior Brasileira como fator decisivo da evolução jurídica implica uma mudança no pensamento dos julgadores, por meio do desvelamento do texto constitucional diante do caso concreto, para ir rumo à instituição de direitos.

A par disso, mediante o processo, assim considerado um instrumento jurisdicional democrático, ousado e em constante aperfeiçoamento, no qual se efetivam os direitos humanos, o STF tem exercido consoante a uma interpretação filosófica-constitucional em que a Constituição, ao contemplar direitos, deve reproduzi-los por meio de uma representação do presente, quando o objetivo maior é o cumprimento dos direitos fundamentais. Essa postura reflete um novo fenômeno, havendo uma visível passagem do Gesetzstaat ao Richterstaat, isto é, a passagem do poder Legislativo para a predominância do poder Judiciário, uma vez que, como face positiva, significa dizer que o manto da Justiça tem servido para atender às singelas e complexas demandas da sociedade contemporânea.

Não se quer com isso desmerecer a atuação dos demais poderes, mas sim enfatizar a necessidade de aperfeiçoamento de tais entes, pois a maior beneficiária será a sociedade como um todo, bem como prestigiar o valoroso trabalho prestado pelo Supremo Tribunal Federal em prol da concretização dos direitos humanos.

1988, a capacitação em cursos sobre direitos humanos e a intervenção nas políticas públicas, evidenciam o papel do MNDH como uma das organizações que mais têm contribuído para o sistema nacional de proteção desses direitos no Brasil. 
Nem se alegue por parte dos setores mais conservadores da sociedade a ocorrência de eventual violação da separação de poderes, visto que, dentre as diversas causas que justificam esse comportamento proativo do Supremo Tribunal Federal na proteção dos direitos humanos inclui-se a necessidade de fazer prevalecer os tratados e convenções assinados pelo Brasil, muitas vezes infringidos por total descaso e omissão dos poderes majoritários. Se é certo que o protagonismo do Supremo Tribunal Federal incomoda muita gente, o silêncio dos demais poderes incomoda muito mais.

Diante desse cenário brasileiro, em que temos como exemplos de grupos minoritários que vêm tendo seus direitos humanos atingidos no Brasil, a Corte Superior passa a ter o papel indiscutível de se inserir na preservação dos valores fundamentais, mesmo que isso signifique ir contra as decisões da maioria, então representadas pelos poderes Executivo e Legislativo. Isto porque, na concepção de Luís Roberto Barroso, "O Estado não pode adotar medidas nem interpretações que provoquem a exclusão jurídica de grupos minoritários” (Barroso, 2009).

Ainda com relação ao Brasil, salienta-se a Súmula Vinculante $\mathrm{n}^{0} 25$ do Supremo Tribunal Federal, que foi editada em 2009 e representou um marco para os direitos humanos no Brasil, por consagrar o status supralegal dos tratados de direitos humanos, negando, assim, que as normas internas que conflitarem com os dispositivos do tratado sejam aplicadas (Bernardes, 2011).

Por tudo isso, o real sentido dos direitos humanos se exsurge para a Corte Superior Brasileira, cujo papel vai muito além de mero julgador, tendo o desafio de enfrentar e realizar a promoção dos direitos humanos pelos mecanismos postos a sua disposição, cuja aplicação deve ocorrer por meio de uma interpretação, que tenha como pressuposto essencial para a construção do Estado Democrático de Direito as condições da dignidade da pessoa humana. 


\section{O SISTEMA REGIONAL INTERAMERICANO DE DIREITOS HUMANOS NA DEMOCRACIA CONTEMPORÂNEA}

Como é de conhecimento geral, além de existir o sistema global de defesa em prol do resguardo dos direitos humanos, temos sistemas regionais de proteção, merecendo especial relevo o sistema interamericano,do qual fazemos parte, razão pela qual se torna essencial um estudo mais aprofundado sobre o tema.

\subsection{Origem, conceito, função e composição da Corte Interamericana de Direitos Humanos}

A Segunda Guerra Mundial foi o ápice para a emergência por parte dos povos de diversas partes do mundo, em prol da criação de sistemas de proteção dos direitos humanos que, efetivamente, apresentassem formas de torná-los eficazes.

Nesse sentido Fernanda Frizzo Bragato observa:

A partir da segunda metade do século XX, vem-se assistindo a um contínuo aparecimento de mecanismos legais para a proteção dos direitos humanos, como forma de evitar que se transformem em retórica vazia (in Culleton; Bragato; Fajardo, 2009, p. 105).

A consequência desse fenômeno, caracterizado pelo aparecimento de diversos mecanismos, foi a positivação de tais direitos nos ordenamentos nacionais e a criação de sistemas internacionais de proteção de direitos humanos, além de regionalizações desses sistemas, como ocorre com o Sistema Global (toda e qualquer pessoa é sujeito de direito) e o Sistema Regional (engloba pessoas e coletividades específicas, atendendo peculiaridades de determinada região do globo), estabelecendo uma pacífica convivência entre os dois sistemas (Culleton; Bragato; Fajardo, 2009). 
A origem do Sistema Regional Interamericano passa a ser delineada com a proclamação da Carta da Organização dos Estados Americanos, tendo sido esta aprovada na $9^{\text {a }}$ Conferência Interamericana juntamente com a celebração da Declaração Americana dos Direitos e Deveres do Homem. A função principal do Sistema Interamericano de Direitos Humanos refere-se ao inegável legado que os países que integram a Organização dos Estados Americanos (OEA) possuem de zelar pela proteção dos direitos fundamentais.

O Sistema Interamericano de Direitos Humanos engloba quatro instrumentos, quais sejam, a Carta da Organização dos Estados Americanos (1948), a Declaração Americana dos Direitos e Deveres do Homem (1948), a Convenção Americana sobre Direitos Humanos (1969), conhecido comumente como Pacto de San José da Costa Rica, e, por fim, o Protocolo de San Salvador (1988), que se constitui em um protocolo adicional à Convenção Americana no que se refere aos direitos econômicos, sociais e culturais.

Foi em 1948, na 9 ${ }^{\text {a }}$ Conferência Internacional do Estados Americanos, que se deu o impulso inicial para uma verdadeira proteção aos direitos humanos. Foi nessa Conferência que se assinou a Declaração Americana dos Direitos e Deveres do Homem, assim como a Carta da Organização dos Estados Americanos e se propôs a criação de uma Corte que efetivasse e materializasse os acordos nos quais os países estavam se inserindo. Foi então em 1959 criada a Comissão Interamericana de Direitos Humanos, que não tinha a competência de punir os Estados que violassem os tratados. Somente a Corte, criada em 1978, abrangeu essa competência e começou a julgar e punir os Estados. Ela tem sua sede em San José da Costa Rica.

Expressamente compete a ela receber por meio da Comissão Interamericana denúncias de violações de direitos por parte dos Estados. Nenhuma pessoa física consegue interpor uma ação perante a Corte. $\mathrm{Ou}$ 
seja, quando a Comissão envia relatórios e recomendações aos Estados para que cessem e/ou revertam as violações, e se entender que esse Estado não cumpriu com as determinações, a Comissão envia o caso à Corte.

\subsection{Casos brasileiros submetidos à Corte Interamericana de Direitos Humanos}

Tendo em vista que a Corte Interamericana de Direitos Humanos integra o Sistema Interamericano de Proteção dos Direitos Humanos, segue-se análise de alguns casos brasileiros.

\subsubsection{Caso 1 (Guerrilha do Araguaia x Brasil)}

Na petição $\mathrm{n}^{\circ}$ 11.552, mais conhecido como caso Julia Gomes Lund e Outros x Brasil, o Estado brasileiro foi condenado por ter violado diversos direitos fundamentais dos opositores ao regime militar que vigorava na época. Na denúncia consta que o Brasil é culpado pela detenção, tortura e desaparecimento de cerca de 70 pessoas entre os anos de 1972 e 1975 na Região Norte do Brasil. Os crimes teriam sido praticados pelo Exército Brasileiro, que interveio na área, a fim de fazer cessar as manifestações de moradores e membros do Partido Comunista do Brasil (PCdoB) pelo fim da ditadura militar. Em 1982 um processo foi interposto na Justiça Federal brasileira por um grupo de parentes das vítimas. Decorridos 13 anos, e sem uma resposta do órgão julgador, os familiares resolveram denunciar os abusos junto a Comissão Interamericana de Direitos Humanos. Dentre os direitos violados é visível a detenção arbitrária, tortura e desaparecimento de 70 pessoas, estendendo-se, portanto, à violação de direitos à personalidade jurídica, à integridade física e à vida, além de ter sido ofendida também a liberdade de pensamento e expressão. 
Ainda sob alegação de estar amparado pela Lei da Anistia, o Estado brasileiro não proporcionou a legítima investigação criminal dos fatos ocorridos, acarretando na violação dos direitos a garantias judiciais e proteção judicial.

A Corte entendeu, em 2010, que o Brasil foi culpado pelo desaparecimento de 62 pessoas que participaram da denominada Guerrilha do Araguaia, e obrigou o Estado a retomar as buscas pelos corpos, além de oferecer um curso sobre direitos humanos a todos os integrantes das Forças Armadas. Recentemente, em julho de 2012, a Advocacia Geral da União iniciou vários processos para o pagamento de indenização pecuniária às famílias das vítimas, no valor de US\$ 1,2 milhão (equivalente a R\$ 2.593.305). Importante salientar que foi a primeira e única condenação do Brasil por crimes cometidos durante a ditadura militar.

\subsubsection{Caso 2 (Damião Ximenes Lopes x Brasil)}

O caso Damião Ximenes Lopes x Brasil é muito importante, por ter sido a primeira sentença, proferida em 2006, que condenou o Estado brasileiro por violação de direitos inerentes à dignidade da pessoa humana. Em 1999 a irmã da vítima, Irene Ximenes Lopes, entrou com denúncia perante a Comissão Interamericana de Direitos Humanos contra o Estado brasileiro pela violação à integridade física e à vida de seu irmão, portador de doença mental, que fora internado em uma clínica destinada ao tratamento de pessoas com necessidades especiais, vinculada ao Sistema Único de Saúde. Na denúncia da petição $\mathrm{n}^{\mathrm{0}} 12.237$, consta que seu irmão fora vítima de maus-tratos causados pelos enfermeiros da clínica que, em dado momento, teriam entrado em luta corporal com a vítima, e após, teriam constatado a morte de Damião. No laudo assinado pelo então diretor da clínica, causa estranheza quanto ao esclarecimento da real causa da morte. A irmã da vítima teria esgotado todas as possibilidades na jurisdição brasileira, assim como foi constatada a dificuldade de obtenção de provas. Não 
lhe restava então outra alternativa a não ser ingressar com uma ação na Comissão Interamericana de Direitos Humanos visando à reparação do dano causado pelo descaso tanto por parte da clínica vinculada ao SUS, quanto por parte da análise da maneira como os tribunais brasileiros trataram o caso, ante tamanha violação de direitos fundamentais.

A violação da integridade física e à vida, assim como a falta de garantias processuais foram os direitos mais violados nesse caso. Tendo em vista a situação da vítima e o dever do Estado de proteger as pessoas que estão em situação vulnerável, como era o caso de Damião Ximenes Lopes, é visível que houve negligência por parte do Estado brasileiro em garantir esses direitos básicos prescritos na Constituição Federal. Foi instaurado um processo interno para investigação do caso, e, se preciso, responsabilização penal dos envolvidos diretamente em tais atrocidades. Em junho de 2009 a Comarca de Sobral, Ceará, emitiu uma sentença condenatória, que sofreu um recurso depois. A sentença de mérito foi proferida em 4 de julho de 2006, condenando o Brasil ao pagamento de indenização à família da vítima, além de medidas de formação e capacitação de pessoal médico que trabalha em clínicas destinadas a receber pessoas com deficiências mentais. Segundo relatório, a Corte entende que o Brasil vem se empenhando em responsabilizar os culpados pela morte de Damião, e, segundo o último relatório anual, emitido em 2011, continua supervisionando o processo penal em andamento, assim como as outras obrigações impostas ao Brasil.

\subsubsection{Caso 3 (Nogueira de Carvalho x Brasil)}

Em 13 de janeiro de 2005 a Comissão Interamericana de Direitos Humanos submeteu à Corte a demanda de investigar a responsabilidade do Estado brasileiro no chamado caso Nogueira de Carvalho. Na demanda 
constava a suposta violação dos direitos previstos na Convenção Americana, como a garantia e proteção judiciais e dever de respeitar os direitos.

Foi em 11 de dezembro de 1997 que o Centro de Direitos Humanos e Memória Popular, o Holocaust Human Rights Project e o Group of International Human Rights Law Students submeteram denúncia à Comissão Interamericana pela morte de Gilson Nogueira de Carvalho, advogado, forte defensor dos direitos humanos no Brasil, que desenvolvia esforços pelo fim do grupo de extermínio denominado "Meninos de Ouro" que atuavam no Rio Grande do Norte, Brasil. Nogueira de Carvalho foi morto com 17 tiros em frente a sua casa, em 1996. Havia denúncias de envolvimento de policiais civis na atuação do grupo. A Comissão solicitou, em 2005, perante a Corte, a condenação do Brasil pelo fato de terem se passado dez anos da instalação de processo interno para a apuração do caso, sem terem sido responsabilizados os verdadeiros culpados pela morte de Nogueira de Carvalho. E foi em 26 de novembro de 2006 que a Corte sentenciou a demanda, tornando este o primeiro e único caso em que se entendeu a não culpabilidade do Brasil pela negligência nas investigações do ocorrido, assim como pela violação de direitos consagrados na Constituição Federal e Convenção Americana.

\subsubsection{Caso 4 (Escher e outros $\times$ Brasil)}

Em 2000 o MST, a Justiça Global, a Comissão Pastoral da Terra (CPT), a Terra de Direitos e a Rede Nacional de Advogados e Advogadas Populares (Renap) entraram com demanda na Comissão Interamericana denunciando a quebra de sigilo telefônico de militantes do MST.

Segundo a denúncia, houve facilitação por parte da juíza Elizabeth Khater no pedido de grampeamento das linhas telefônicas. Ela favoreceu o pedido do então major Waldir Copetti Neves, da Polícia Militar de 
Paraná, sem nenhuma fundamentação legal, o que resultou em 49 dias de escutas telefônicas ilegais, que foram dolosamente editadas a fim de insinuar supostos ataques que os ativistas do MST estavam planejando. Isso culminou em uma revolta de ruralistas e autoridades, que assassinaram 16 trabalhadores rurais. A demanda aceita pela Corte foi sentenciada em 2009, condenando o Brasil a indenizar as vítimas em um prazo razoável, realizar ato público de reconhecimento de responsabilidade internacional, investigar os fatos que geraram as mortes e as violações dos direitos, restituir as custas do processo, entre outras medidas cabíveis.

\subsubsection{Caso 5 (Sétimo Garibaldi x Brasil)}

As organizações Justiça Global, Rede Nacional de Advogados e Advogadas Populares (Renap) e Movimento dos Trabalhadores Rurais Sem Terra (MST), na data de 6 de maio de 2003, apresentaram petição em nome de Sétimo Garibaldi e seus familiares, tendo a Comissão emitido em 27 de março de 2007 recomendações para o Estado. Tendo em vista que o relatório foi notificado ao Brasil em 24 de maio de 2007, nada tendo feito no prazo de dois meses (e ainda assim, tendo sido concedida uma prorrogação) acerca da execução das recomendações feitas pela Comissão, este caso foi submetido perante a Corte e representou uma oportunidade para o desenvolvimento da jurisprudência interamericana sobre os deveres de investigação penal do Estado perante as execuções extrajudiciais.

Esse caso envolve a responsabilidade do Estado perante o descumprimento da obrigação de investigar e punir o homicídio de Sétimo Garibaldi, ocorrido durante uma operação extrajudicial de despejo das famílias de trabalhadores sem-terra, que ocupavam uma fazenda, tendo a Comissão solicitado à Corte declarar a responsabilidade do Estado pela violação às garantias jurídicas, proteção judicial, garantia dos direitos humanos e o dever de adotar medidas legislativas e de outro caráter no âmbito interno. 
Na sentença, proferida em 23 de setembro de 2009, a Corte entendeu que o Estado violou os direitos às garantias judiciais e à proteção judicial em prejuízo da esposa e filhos do senhor Garibaldi, condenando o Estado a publicar a sentença impressa e na mída, conduzir inquérito para identificar, julgar e, eventualmente, sancionar os autores da morte do senhor Garibaldi, pagamento à esposa e filhos a título de dano material e imaterial, restituição de custas e gastos despendidos pela família de Garibaldi no decorrer do processo.

\subsection{O futuro do Sistema Interamericano de Direitos Humanos e a democracia}

No decorrer dos últimos tempos algumas discussões vêm sendo delineadas sobre o futuro do Sistema Interamericano de Direitos Humanos, pois a sua crescente influência perante os países membros da OEA ao representar a redefinição da hegemonia dos Estados-nação como únicos sujeitos do Direito Internacional impôs limites à soberania dos países, colocando os direitos humanos como pauta de proteção internacional.

Em nosso entendimento, as análises minuciosas por parte de tais instituições internacionais são absolutamente necessárias, para evitar que as ações dos governos desencadeiem resultados funestos e que acabem por romper com as ideias de um verdadeiro Estado Democrático de Direito, comprometido com a defesa dos direitos humanos.

Preocupados com esse cenário, Darci Guimarães Ribeiro e Felipe Scalabrin alertam:

As estruturas do sistema acabam por assegurar direitos apenas a determinados tipos de povo, ora povo-ativo ora povo-ícone, contudo esquecem-se que a democracia é, acima de tudo, feita para todos e que mesmo que não seja construída por todos deve, obrigatoriamente, ser exercitável por todos. Não é sem rumo que temos presente em nosso ordenamento o acesso irrestrito ao poder Judiciário, segundo se depre- 
ende do inc. XXXV, do art. $5^{\circ}$ da CF. Através deste direito fundamental, as incompatibilidades existentes no meio social se tornam resolúveis e todo indivíduo tem a potencialidade de ser ouvido e ter sua causa satisfatoriamente atendida (2009, p. 57).

É indiscutível essa valorização do processo e do acesso irrestrito ao poder Judiciário, o que também é válido ao nos referirmos à Comissão e à Corte Interamericana de Direitos Humanos, visto que ambas representam instâncias internacionais na defesa dos direitos humanos, os quais são tão promovidos como bandeiras das nações democráticas, e, ao mesmo tempo, tão desrespeitados.

Tais direitos humanos se efetivam por intermédio do processo judicial, entendido como o instrumento mais apto a assegurar as garantias constitucionais, tendo no povo ${ }^{10} \mathrm{o}$ ápice da democracia, assim considerado como sujeito de interesses tutelados, protegido pela possibilidade de apreciação de seus conflitos.

A maior prova da existência da democracia em uma nação é, obviamente, o respeito aos direitos humanos, e a recusa ao cumprimento das decisões da Corte Interamericana de Direitos Humanos é, no mínimo, conivência com tais violações, o que é inadmissível nas nações democráticas. A ausência de mecanismos coercitivos por parte da Corte constitui-se em um dos problemas globais que representam um óbice para o futuro do Sistema Interamericano.

\footnotetext{
${ }^{10}$ Inescusável falarmos sobre democracia, sem que seja aberta uma fenda para as diversas concepções acerca do povo, considerado pilar essencial da democracia, mas qual seria o papel do povo no discurso democrático? Para responder essa questão, nos utilizamos das conceituações de povo desenvolvidas por Friedrich Müller, na sua obra Quem é o povo? A questão fundamental da democracia (2010), no sentido de que o cidadão é muito mais que mero ícone-signo representativo do Estado, representando um legítimo ator principal em uma sociedade livre, solidária e justa, tendo nos deslindes do Estado Social o mais apto a consagrar os valores do sistema democrático.
} 
Constata-se, portanto, que o compromisso da comunidade internacional com a proteção internacional efetiva dos direitos humanos é pilar essencial para o futuro da Corte Interamericana, valoroso órgão a serviço das finalidades mais nobres.

A este respeito, a responsabilidade dos Estados-Membros é, também, indiscutível, para que se possa cumprir as sentenças de forma eficaz, o que, muitas vezes, encontra óbice na vontade política por parte do país responsável pelas violações de direitos humanos.

Nesse sentido, recentemente o Brasil desqualificou publicamente a competência internacional da Comissão Interamericana de Direitos Humanos, no caso de Belo Monte, culminando em um atroz retrocesso nas relações até então amistosas entre o Brasil e a Comissão. Assim, iniciou-se uma discussão ainda mais profunda sobre o futuro do Sistema Interamericano de Direitos Humanos, devendo ser dito, neste primeiro momento, que o papel de zelar pelo respeito e promoção de tais direitos adquire ainda mais relevância ao se constatar violações cada vez mais gritantes na sociedade. Ao causar constrangimento internacional para que suas recomendações fossem cumpridas, a $\mathrm{CIDH}$ foi alvo de ataques violentos, tendo o Brasil reagido com desprezo ao desqualificar publicamente a competência da Comissão. Essa não foi a única manifestação ofensiva por parte do Estado brasileiro, que acabou por retirar seu embaixador na OEA e não pagar sua cota por meses, provocando um profundo mal-estar envolvendo o Brasil e a comunidade internacional (Ventura; Piovesan; Kweitel, 2012).

Atualmente a Corte Interamericana de Direitos Humanos é a instituição que protege ativamente os direitos humanos em nossa região, tendo a Convenção Americana (Pacto de San José da Costa Rica) feito grandes reformas em seus mecanismos de proteção, transformando-o em principal responsável pelo sistema interamericano. 
Essas preocupações acerca do futuro da Corte Interamericana, apesar de serem cada vez mais discutidas, não são um problema recente, pois, em novembro de 1996, o secretário geral da OEA, César Gaviria Trujillo, apresentou a consideração do Conselho Permanente, por meio do documento "Por uma nova visão do sistema interamericano de direitos humanos”, no qual se identificavam os problemas existentes e propostas de soluções concretas (Cançado Trindade, 2004).

Isso posto, no $20^{\circ}$ aniversário da Corte Interamericana, em janeiro de 1999 uma comissão presidida pelo então vice-presidente, Antônio A. Cançado Trindade, organizou um seminário com o objetivo de debater o fortalecimento do Sistema Interamericano e propor as soluções mais adequadas para resolver os problemas que então se apresentavam.

Impende mencionar que a preocupação com o cumprimento das sentenças da Corte Interamericana de Direitos Humanos é um dos aspectos que já vem sendo alvo de preocupação desde meados de 1996. Tanto isso é verdade que, quando essa preocupação passou a ocorrer, foram propostas sugestões por parte dos Estados para o cumprimento das sentenças, entre as quais as de que

las resoluciones de La Corte y, en su caso, de su Presidente, una vez comunicadas a las autoridades administrativas o judiciales correspondientes de La República, tendrán la misma fuerza ejecutiva y ejecutoria que las dictadas por los tribunales costarricenses (Cançado Trindade, 2004, p. 136).

Os participantes do seminário "El Sistema Interamericano de Protección de Los Derechos Humanos en el umbral del siglo XXI", ocorrido nos dias 23 e 24 de novembro de 1999, manifestaram que a execução se encontra pautada por três princípios indispensáveis: a) a decisão da Corte será definitiva e inapelável; b) os Estados-Partes da Convenção se comprometem a cumprir as decisões da Corte em todos os casos em que sejam partes e c) o cumprimento das decisões da Corte está sujeito à supervisão 
do próprio Tribunal, tanto em sentença de mérito quanto em sentença de reparações (Cançado Trindade; Robles, 2004, p. 138). Ademais, existe a necessidade de adoção de medidas nacionais indispensáveis de instituição da Convenção, de forma a assegurar a aplicabilidade direta de suas normas no Direito interno dos Estados-Partes, por meio da adoção de mecanismos internos de execução das sentenças da Corte. Além disso, quando o Estado deixa de cumprir uma sentença proferida pela Corte, incorre em uma (nova) violação adicional à Convenção (Cançado Trindade; Robles, 2004).

Acreditamos que, sem desmerecer o papel da Comissão e da Corte, as quais possuem uma importância indiscutível, é necessário que o indivíduo tenha ampla liberdade para propor a demanda, visto que sendo ele, o cidadão, o legítimo titular de tais direitos, deve possuir formas de fazer valê-los no âmbito processual, e assim possibilitar um alcance mais pleno da democracia.

A respeito desse assunto, Darci Guimarães Ribeiro e Felipe Scalabrin afirmam:

A verdadeira práxis democrática, configuradora de um autêntico Estado de Direito, reside principalmente na efetiva concretização dos direitos e garantias fundamentais e não em meras abstrações legais contidas em um texto normativo. Estes direitos e garantias fundamentais, por sua vez, somente ganham vida através do mais afinado instrumento democrático: o processo. Ele, o processo, se constitui no mais valoroso elemento vivificador das aspirações de uma sociedade reprimida de justiça social, pois encontra no irrestrito acesso ao Judiciário, no contraditório, na publicidade e na fundamentação os mais altos desígnios da verdadeira democracia. É através dele, o processo, que os "cidadãos revelam ser sujeitos práticos justamente pela práxis: como atores que estão a cada dia dispostos a lutar pela honestidade e pelo tratamento materialmente igual das pessoas no Estado e na sociedade” (2009, p. 53-66). 
Em relação aos aspectos processuais, alguns Estados criticam a repetição da prova perante a Corte, depois de ela já ter sido feita na Comissão, entendendo que se deve resguardar o seu controle pelas partes, como forma de garantia do direito da defesa das partes no processo. Ainda sobre a prova, é interessante constatar a sugestão de que as provas devem seguir uma valoração não somente por um critério lógico-formal, mas também por um critério estimativo, valorando-se a prova da forma que seja mais adequada para a proteção dos direitos humanos, tendo em vista a evidente desigualdade existente entre as partes.

Ademais, para que seja possível o fortalecimento do sistema interamericano de proteção dos direitos humanos, por meio do cumprimento das recomendações e sentenças feitas, sem dúvida é necessário que os Estados utilizem os recursos econômicos adequados e indispensáveis para esta finalidade.

Por fim, conclui-se que a democracia como instituição do Estado Democrático de Direito está diretamente relacionada com a contínua transformação do mundo, calcada no permanente diálogo e consenso entre os povos e demais atores sociais, residindo na efetiva concretização das garantias fundamentais, as quais só ganham vida diante de um harmonioso instrumento: o processo.

\section{LIMITES E POSSIBILIDADES PARA A EFICÁCIA DAS SENTENÇAS PROLATADAS PELA CORTE INTERAMERICANA DE DIREITOS HUMANOS}

Reconhecida a importância da discussão que interliga a temática dos direitos humanos como um assunto de emergência mundial com a necessidade de respeito pelos países que se comprometeram com a concretização dos direitos humanos, passaremos a analisar os limites e as possibilidades para a eficácia das sentenças prolatadas pela $\mathrm{CIDH}$. 


\subsection{Eficácia interna das sentenças prolatadas pela CIDH envolvendo o Brasil}

A eficácia jurídica das sentenças internacionais de direitos humanos depende, entre outros fatores, do correto funcionamento dos mecanismos de cooperação e assistência judicial internacional. Se é verdade que o ordenamento jurídico brasileiro contempla os direitos humanos, há que se ter os instrumentos legais para torná-los efetivos. A primeira observação a ser feita refere-se à diferença entre sentença estrangeira e sentença internacional, pois nada se menciona em nossa legislação sobre o cumprimento à última, ensejando algumas reflexões: Se a sentença estrangeira é diferente da sentença internacional, o que fazer diante disso? A fim de esclarecermos esse questionamento, a diferença entre elas, é que, no primeiro caso estamos diante de uma sentença que é prolatada no estrangeiro, nos termos jurídicos do Direito de determinado Estado, e no caso da sentença internacional, é aquela proferida por organismos internacionais e com poderes jurisdicionais, tendo como fonte normativa os tratados. Assim, são consideradas sentenças internacionais todas aquelas proferidas por tribunais internacionais, que julguem Estados, que aceitaram se submeter à solução por parte de uma instância internacional (Pereira, 2009).

Em nosso entendimento, a sentença internacional, por estar revestida de conteúdo conglobante dos direitos humanos, possui (ou ao menos deveria possuir) eficácia plena, sendo, portanto, de execução imediata, cabendo à União (representante do Estado no cenário internacional) providenciar a sua execução nos termos estipulados pela Corte Interamericana.

Alguns autores mais radicais, como Maeoka, entendem que sequer pode ser chamada de sentença jurisdicional aquela que não possui, essencialmente, os atributos coercitivos que contêm qualquer decisão judicial (Ambos; Malarino; Alsner, 2007). 
Todos os signatários da Convenção obrigaram-se internacionalmente a executar os acórdãos da Corte, sob pena de responsabilização internacional, razão pela qual não podem se utilizar de argumentos pouco sólidos como justificativa para que a sentença não seja obrigatória.

Como mencionado anteriormente, o Brasil sempre se destacou no plano internacional como defensor dos direitos humanos, englobando mecanismos e procedimentos previstos tanto na Carta da Organização dos Estados Americanos quanto em outros instrumentos jurídicos que têm correlação com ela (Jayme, 2005).

Em relação à execução das sentenças da Corte Interamericana de Direitos Humanos em âmbito interno brasileiro, salienta-se que somente o poder Executivo e o poder Legislativo possuem as formas legais para executar a sentença. Ainda assim, alguns autores entendem que a mesma pode ocorrer de duas maneiras, quais sejam: execução forçada pelo poder Judiciário ou de forma espontânea pelo Estado.

A instituição automática pelo Estado é a regra, sendo, pois, obrigatória, assim como as decisões do poder Judiciário. Tal obrigatoriedade se dá devido à ratificação da Convenção Americana, assim como pelo reconhecimento da competência contenciosa da Corte pelo Estado brasileiro. Havendo cumprimento espontâneo, não haverá a necessidade de se procederem formas judiciais para a sua concretização no âmbito interno brasileiro.

O Pacto de San José da Costa Rica afirma que a parte da decisão que dispor sobre indenização poderá ser executada no devido país de acordo com o procedimento interno aplicável à execução de sentenças contra o Estado, de acordo com o inciso $2^{\circ}$ do artigo 68 do Pacto, cuja norma, conforme Rescia, permite materializar, em última instância, o cumprimento da sentença indenizatória. Essa viabilidade de execução, real e eficaz, fortalece ainda mais as decisões da Corte (Rescia, 1994). 
No caso do Brasil, as indenizações são pagas por meio de precatórios, regido pelos pilares do artigo 100 da Constituição da República e nos artigos 730 e 731 do Código de Processo Civil. E a obrigatoriedade de a vítima ter de passar a se submeter á morosidade desse sistema acaba tornando a espera ainda mais degradante e desumana.

Em relação às reparações não pecuniárias ordenadas pela Corte Interamericana devem ser cumpridas conforme estabelecido pelo Direito interno, segundo o artigo 461 do Código de Processo Civil. Neste sentido Llorens afirma:

A Corte Interamericana, tal como a Corte Européia, não é um tribunal penal e não substitui as ações penais relativas às violações cometidas nos Estados. A Corte apenas julga se o Estado é ou não responsável pelas violações à Convenção Americana. Quando o Estado é responsabilizado, a consequiência é a obrigação de fazer cessar a violação e indenizar a vítima ou seus herdeiros legais (2001).

Caso o país que for condenado receber a notificação formal da CIDH, a administração pública deve tomar as devidas providências para a real efetivação da sentença proferida, sob pena de ser responsabilizado internacionalmente, assim vislumbra Coelho:

Em caso de condenação, após receber a comunicação formal da Corte Interamericana sobre a decisão de mérito, o Estado deve adotar as medidas necessárias para proceder a seu cumprimento, sob pena de nova responsabilização internacional. Esse é o dever da Administração Pública após o Brasil ter ratificado o Pacto de São José da Costa Rica e declarado reconhecer a competência obrigatória da Corte Interamericana de Direitos Humanos (Coelho, 2008).

O poder legislativo tem a obrigação de observar os tratados ratificados em nome do Estado, adotando os mecanismos necessários para sua instituição, do contrário o país poderá ser responsabilizado internacionalmente. 
Sobre a efetivação forçada pelo Judiciário, o inciso XXXV do artigo $5^{0}$ da Constituição da República do Brasil afirma que nenhuma lesão a direito pode ser excluída da apreciação do poder Judiciário. Desta maneira, no caso de inércia ou demora injustificada do Estado para proceder à execução da sentença prolatada pela Corte, o poder Judiciário poderá ser acionado pela vítima, seus representantes legais ou pelo Ministério Público.

Em relação à competência, o juiz da $1^{\mathrm{a}}$ instância da Justiça Federal, em geral o da residência da vítima, será competente para executar a sentença da Corte Interamericana.

Podemos ressaltar que, conforme as concepções de Correia, alguns doutrinadores brasileiros entendem que as decisões prolatadas pela Corte Interamericana possuem força de título executivo perante o Direito nacional:

No Brasil, alguns estudiosos - como Cançado Trindade, Celso Renato D. de Albuquerque Mello, Flávia Piovesan - acreditam que as decisões da CIDH têm força de título executivo no direito interno.[...] Quando o Estado condenado não cumpre a sentença, cabe à Corte informar o fato em seu informe anual dirigido à Assembléia-Geral da OEA, onde se materializa uma sanção moral e política (Correia, 2008, p. 133).

Esse entendimento decorre do fato de estarmos diante de uma sentença internacional de direitos humanos, afinal, uma sentença estrangeira do Paquistão, por exemplo, precisa, naturalmente, ser homologada pela Corte Superior Brasileira, e para isso deve atender aos ditames da ordem pública de nosso país (Bernardes, 2011).

O Brasil foi condenado cinco vezes pela Corte Interamericana de Direitos Humanos. Nesse contexto analisaremos agora a execução desses casos: 
a) Caso Damião Ximenes Lopes: ${ }^{11}$ cabe registrar que, quanto à eficácia da sentença proferida pela Corte, a solução do caso foi extremamente demorada. Passaram-se exatamente seis anos do entendimento de culpabilidade do Brasil no caso, e ainda não temos um caráter definitivo no que respeita à responsabilização dos culpados pela violação dos direitos humanos. Sem contar que a denúncia foi recebida pela Comissão em 1999 e dirigida à Corte em 2004, e desde a morte de Damião já se passaram mais de dez anos em que a família espera uma resposta definitiva para o caso. Quanto à responsabilização atribuída à clínica e aos enfermeiros encarregados do tratamento de Damião, em 2009, foram condenados a seis anos de prisão em regime semiaberto. Apesar dos problemas apresentados (e que ainda estão sendo enfrentados), foi um marco para o presente, repercutindo na política de saúde mental do Brasil, por meio da Lei no 10.216 de 6 de abril de 2001, dispondo sobre a proteção e os direitos das pessoas com transtornos mentais (Rosato; Correia, 2011).

b) Caso Guerrilha do Araguaia:12 quando se olha para o caso Gomes Lund (Guerrilha do Araguaia) vemos um problema ainda maior na eficácia. Com início das violações nos anos 70, a última ação do Brasil na tentativa de cumprir com a condenação pela Corte foi o depósito, no mês de julho de 2012, de cerca de US\$1,2 milhão (equivalente a R\$ 2.593.305) aos parentes dos militantes desaparecidos. Ou seja, passaram-se mais de trinta anos da tortura e desaparecimento dos corpos das vítimas, e o Brasil ainda continua executando a sentença que foi proferida em 2010. Além disso, essa demora dificulta a responsabilização dos envolvidos

${ }^{11}$ Caso $\mathrm{n}^{\mathrm{o}} 12.237$ da Corte Interamericana de Direitos Humanos. Sentença da Corte em 4.7.2006.

${ }^{12}$ Sentença da Corte em 24.11.2010. 
diretamente no caso, como na Guerrilha do Araguaia, em que temos mais de trinta anos do início das violações, sem uma concreta responsabilização e punição dos militares envolvidos.

c) Caso Nogueira de Carvalho: ${ }^{13}$ quanto a este caso o Estado afirmou que houve investigação séria e em prazo processual adequado para a responsabilização dos suspeitos envolvidos na morte do advogado Nogueira, no entanto a grande complexidade do caso, com muitas versões sobre a autoria e um excessivo número de suspeitos, foram a justificativa para que o processo não resultasse em uma condenação.

Nesse caso, o Estado não foi responsabilizado por não se entender que tenha havido violação ao devido processo legal, ainda que em nosso entendimento tenha havido uma falha em alguns pontos, tais como o fato de a Polícia Federal não ter interrogado os policiais que supostamente participavam do grupo de extermínio.

d) Caso Escher: ${ }^{14}$ esse caso, envolvendo interceptação e monitoramento telefônico ilegais realizados pela Polícia Militar do Estado do Paraná, sem reparação de danos às vítimas, teve entre uma das exigências da Corte a publicação da sentença em jornal de grande circulação, por entender que representa um passo importante para o cumprimento do ordenado pela Corte. O Estado alegou que a extensão do texto exigiria

\footnotetext{
${ }^{13}$ Caso $\mathrm{n}^{\circ} 12.058$ da Corte Interamericana de Direitos Humanos. Sentença da Corte em 26.11.2006. Esse caso envolvia a violação da proteção judicial e das garantias judiciais em detrimento de Jaurídice Nogueira de Carvalho e Geraldo Cruz de Carvalho, pela falta de diligência no processo de investigação dos fatos e punição dos responsáveis pela morte de Francisco Gilson Nogueira de Carvalho. As vítimas são pais de Gilson, advogado defensor de direitos humanos que se dedicou a denunciar os crimes cometidos pelos "Meninos de Ouro", grupo de extermínio integrado por policiais civis e outros funcionários estatais. Gilson foi assassinado na cidade de Macaíba, Estado do Rio Grande do Norte, e seu trabalho resumia-se a tentar acabar com a situação de impunidade envolvendo agentes do Estado que sequestravam, torturavam e matavam pessoas sem que fossem punidos.
}

${ }^{14}$ Sentença da Corte em 20.11.2009. 
a publicação em separado do jornal, com o que a Corte não concordou por entender que não implica que o conteúdo não possa ser compreendido.

Diante disso, o Estado propôs, então, a possibilidade de leitura de um resumo da sentença em um programa de rádio, e, ainda um resumo do caso e da sentença em um quarto de página de jornal de ampla circulação, o que foi negado pela Corte, exigindo o seu cumprimento tal como foi proferida.

e) Caso Sétimo Garibaldi: ${ }^{15}$ quanto à execução da sentença, com base na supervisão de cumprimento de sentença de 20 de fevereiro de 2012, constata-se que, quanto à obrigação de investigar os fatos do caso e encontrar o responsável, o Brasil conduziu uma investigação, no entanto alegou a impossibilidade de responsabilizar os agentes que atuaram no inquérito policial, pois as infrações estariam prescritas. Diante disso, a Corte solicitou que ainda assim se reconheça a responsabilidade de tais agentes e facilite o acesso da família à verdade dos fatos acerca da morte do senhor Garibaldi. A indenização dos danos e restituição de custas e gastos foram realizados pelo Estado brasileiro em 16 de março de 2011.

\subsection{Limites que impedem a eficácia plena no plano interno das sentenças prolatadas pela Corte Interamericana de Direitos Humanos}

A defesa teórica dos direitos humanos não basta. Nesse sentido, é necessário reconhecer que cada sociedade, independentemente da época, da situação política, social, econômica, precisa ter direitos intrínsecos a sua existência. Aqui cabe citar a moral e a ética como condição de evolução humana (e sua continuidade). É neste contexto que há de ser enfatizada

${ }^{15}$ Caso $^{\mathrm{o}}$ 12.478. Sentença da Corte em 23.9.2009. 
a colocação de Wilson Engelmann: “[...] uma sociedade que desrespeita os direitos humanos, contraria um elemento valorativo - proveniente da ética e da Justiça - que retira a legitimidade daquela atuação estatal” (2009, p. 79).

Assim sendo, é preciso perceber um certo equilíbrio quando se olha para a Constituição Federal, por exemplo, e a sociedade sobre a qual ela exerce poder. Nessa perspectiva, nota-se que no Brasil não há uma correta homogeneidade, como deveria ter, para garantir a defesa dos direitos humanos e a dignidade de cada cidadão. Sem dúvida que os aspectos históricos, políticos, a ascensão do Brasil no cenário internacional, enfim, tudo isso pode ser levado em conta na hora de constatar a necessidade de evolução na efetivação dos direitos humanos.

A História do Brasil é marcada por uma significativa existência de desigualdade social, problemas de acesso à Justiça, desrespeito por parte dos que têm mais poder sobre os vulneráveis. A sociedade, porém, como aquela que dá importância e sentido à permanência da atuação e luta dos e pelos direitos, precisa perceber o seu exclusivo papel nesse sentido e não deixar enfraquecer sua atuação.

Um dos maiores problemas que dificultam a eficácia das sentenças prolatadas pela Corte é o próprio desconhecimento pela sociedade em geral da existência desse mecanismo internacional de defesa dos direitos.

Como já analisado no presente trabalho, no âmbito interno percebe-se uma intensa pressão da população no sentido de fazer valer seus direitos.

Quando se fala no plano externo, no entanto, pouco se percebe em matéria de mobilização social para a concretização das sentenças impostas ao Brasil. Claro que isso não deve ser motivo para a não efetivação dos tratados dos quais nosso Estado é signatário, mas sem dúvida nenhum Estado resiste à mobilização de seu povo. 
Outro fator a dificultar é o temporal. Todas as sentenças prolatadas pela Corte até hoje, condenando o Brasil, demoraram muito tempo para serem executadas. Isso leva a um desgaste emocional de parentes das vítimas, além de passar a imagem de descomprometimento em relação aos casos e a importância da punição dos envolvidos e o consequente enfraquecimento da força impositiva que a Corte tem perante os Estados quando estes violam os direitos básicos.

Essa discussão de temporalidade leva-nos também a um problema ainda mais grave: a punição dos envolvidos diretamente nas violações de direitos, constatando-se a falta de vontade política para que esse problema seja resolvido.

Precisa-se de atores políticos mais comprometidos com a o cumprimento das decisões da Corte Internacional de Direitos Humanos, o que é visto de maneira negativa, uma vez que é indispensável a pressão política para a efetivação da dignidade humana e consequentemente a eficácia das sentenças prolatadas pela Corte.

\subsection{Execução das sentenças de direitos humanos no Direito Comparado}

Pode-se apontar como tendência, tanto necessária quanto positiva, que o Direito Internacional, em matéria de proteção dos direitos humanos, caminha para a fase de efetivação dos direitos, oferecendo às vítimas de violação mecanismos interessantes, como o da petição perante a Comissão Interamericana, ou, ainda, obrigando os Estados a apresentarem relatórios sobre a observância de tais direitos (Accioly; Nascimento e Silva; Casella, 2011).

Tais relatórios objetivam fixar recomendações de condutas aos Estados para a melhoria da situação de direitos humanos em seu território, como é o caso da sentença proferida no caso Ximenes Lopes, condenando 
o Brasil à indenização à família da vítima, assim como foi imposta a adoção de medidas por parte do Estado por meio de capacitação de pessoas que trabalhem em clínicas destinadas ao tratamento de pessoas com necessidades especiais. ${ }^{16}$

A eficácia das sentenças prolatadas pela Corte Interamericana de Direitos Humanos vem sendo um problema recorrente, acontecendo em diversos países além do Brasil, tal como a Argentina, de forma que ainda não se tem conseguido, até o momento, cumprir devidamente sua obrigação de julgar os responsáveis pelas violações de direitos humanos (Gonzáles-Salzberg, 2011).

Na sentença do caso Damião Ximenes x Brasil, em que o Brasil foi condenado ao pagamento de indenização à família da vítima, além de medidas de formação e capacitação de pessoal médico que trabalha em clínicas destinadas a receber pessoas com deficiências mentais, assim como a falta de infraestrutura do sistema de saúde, e.g, verifica-se que, apesar de o Brasil ter tomado iniciativa para o cumprimento, não buscou formas de acelerar o processo para responsabilizar aqueles que cometeram tais atrocidades contra Damião.

Conforme González-Salzberg (2011, p. 115-134):

O Estado não tem conseguido até o momento cumprir devidamente sua obrigação de julgar os responsáveis pelas violações de direitos humanos em nenhum dos casos em que isto foi determinado.

Essa dificuldade em encontrar e punir os perpetradores de violações aos direitos humanos é um problema recorrente no Sistema Interamericano, conforme se percebe na imposição de julgar os responsáveis

${ }^{16}$ Sentença do caso Ximenes Lopes. 
em 42 casos, dentre 70 das sentenças condenatórias. Em nenhum desses casos isto tinha sido cumprido de forma satisfatória até 2008, possuindo um percentual de descumprimento em $73,8 \%$ dos casos analisados.

Em meados de 2011, no Caso Castillo Páez x Peru (2009), envolvendo o desaparecimento forçado de Ernesto Rafael Castillo Páez é que surgiu a primeira exceção a esse lastro de descumprimento.

Quanto à execução das decisões da Corte Europeia de Direitos Humanos na Rússia, por exemplo, constata-se, uma característica exclusiva do sistema europeu: a natureza vinculante de tais decisões e os mecanismos para a supervisão da execução das decisões. Assim sendo, prolatada uma sentença desfavorável, existem três obrigações a serem traçadas pelos Estados-Membros: pagar a compensação, promover medidas individuais em favor da vítima (se for necessário) e tomar medidas preventivas, no sentido de assegurar que violações equivalentes não voltem a acontecer (Issaeva; Sergeeva; Suchkova, 2011). No que diz respeito ao pagamento de indenizações e juros prolatados pela Corte Europeia a Rússia vem cumprindo o seu papel, no entanto enfrenta duras críticas quanto à execução de medidas individuais, havendo três códigos processuais distintos para possibilitar a reabertura de um caso judicial na Rússia, além de a Corte possuir uma carga muito grande de petições oriundas daquele país, o que torna o trabalho ainda mais extenso e desgastante.

Uma outra crítica envolvendo a Rússia refere-se à quantidade de sentenças não executadas, proferidas contra o Estado, que justificavam seu descumprimento, em geral, pela falta de recursos financeiros, inclusive algumas decisões, mesmo com valores bem baixos, só foram cumpridas depois de muitos anos. A partir disso, entrou em vigor a Lei de Compensações, em 4 de maio de 2010, possibilitando a reivindicação de compensação baseada na violação do direito a um julgamento justo e à execução em tempo razoável. 
No caso da efetivação das sentenças da Corte Interamericana de Direitos Humanos na Argentina, constata-se que esse tema leva a uma preocupação cada vez maior, destacada pelo elevado déficit no cumprimento de tais decisões, em geral caracterizadas pela ausência de interesse em julgar os responsáveis pelas violações de direitos humanos. Dito isso, pode ser observado, em sentido contrário, que nos seis casos em que a Argentina foi condenada pela Corte Interamericana, até 2011, buscou cumprir as sentenças de indenizações, custas, despesas, além de realizar ato público de reconhecimento de sua responsabilidade, além de adaptar sua legislação interna consoante aos termos excepcionados na sentença (González-Salzberg, 2011).

Os Estados com índices mais altos de descumprimento das sentenças da Corte Interamericana envolvem Colômbia (68\%) e Paraguai (69\%); por outro lado, os com mais altos percentuais de cumprimento correspondem aos Estados do México, Bolívia e ao Chile. Destaca-se ainda que a Bolívia, Chile e Honduras possuem 100\% de cumprimento nas sentenças exigindo reparações (Laya et al., 2010).

Vale a pena enfatizar o esforço do Peru, visando ao cumprimento das sentenças proferidas por tribunais internacionais, que editou a Lei 27.775, de 5 de julho de 2002, especificamente para cumprir sentenças internacionais, o que por si só torna-se um diferencial por parte dos peruanos, em um cenário em que, atualmente, outros países ainda não diferenciam sentença estrangeira de sentença nacional ou internacional (Pereira, 2009).

Com a promulgação dessa lei no Peru, após o Ministério das Relações Exteriores transmitir a sentença para o presidente da Corte Suprema, este a remete à seção em que se houver esgotado a jurisdição interna relativa à causa, determinando sua execução pelo julgador do processo que antecedeu a sua ida para a Corte Interamericana. Se a condenação versar sobre valores financeiros, o juiz da execução notificará o Ministério 
da Justiça para que providencie o pagamento em até dez dias; no entanto, no caso de sentenças que envolvam medidas não indenizatórias, o juiz da execução determina o prazo que julgar mais adequado para que as instituições que estejam violando o direito de alguém cessem com a situação.

A respeito da execução no Peru, Marcela Harumi Takahashi Pereira alerta para uma questão interessante:

É interessante notar que a própria Convenção Interamericana de Direitos, em seu art. 68.2, prevê que a execução das suas condenações indenizatórias dentro do país sucumbente siga o trâmite da execução de sentenças locais contra a Fazenda Pública. Por outro lado, o Pacto de São José da Costa Rica silencia quanto à execução das demais sentenças, diversamente da Lei 27.775. Poderia, então, questionar-se se o sistema convencionado não seria obrigatório. A verdade, contudo, é que a convenção assegura um mínimo de eficácia interna à sentença internacional. Nada impede que os países, como fez o Peru, ampliem as garantias fornecidas por ela (Pereira, 2009).

Além da Rússia, Argentina e Peru, temos ainda os exemplos trazidos pela Colômbia, que elaborou a Lei 288/1996 a fim de disciplinar o cumprimento de indenizações prolatadas pela Comissão Interamericana, ou, ainda, pelo Comitê de Direitos Humanos do Pacto Internacional de Direitos Civis e Políticos das Nações Unidas. No México constata-se que a Lei sobre Celebração de Tratados, de 2 de janeiro de 1992, mais especificamente, em seu artigo 11, apesar de ressaltar a obrigatoriedade de aplicação dos mecanismos internacionais para a solução das controvérsias, sendo reconhecidos e dotados de eficácia, também possibilita o não reconhecimento da sentença internacional nos casos de violar a segurança do Estado, a ordem pública, ou, ainda, o interesse essencial da nação. Ou seja, no caso deste país, não nos parece haver distinção quanto à sentença internacional e sentença estrangeira. 
Vale destacar que o problema que se apresenta diante do cumprimento da sentença internacional atinge a grande maioria dos países, por não haver, até o momento, um procedimento padrão a ser seguido quanto ao cumprimento, ou, ainda, de mecanismos suficientemente capazes de providenciar a execução de sentença internacional.

Constata-se, portanto, que o maior problema não se refere à instituição das normas internacionais de direitos humanos, nos ordenamentos jurídicos internos, mas sim, à dificuldade em punir os responsáveis pelos delitos enunciados nas denúncias encaminhadas à Corte Interamericana.

\subsection{Possibilidades para o avanço da eficácia das decisões no Brasil}

Tendo em vista que o presente artigo pretende avançar na discussão acadêmica, não somente apresentando o problema, mas suas prováveis soluções, partiremos agora para as sugestões que possibilitem o avanço da eficácia das decisões no Brasil.

Não podemos nos contentar com o que temos, e o esforço brasileiro para possibilitar a eficácia das sentenças prolatadas pela $\mathrm{CIDH}$ continua sendo uma tarefa impostergável. Aprender com outros países continua sendo uma oportunidade única. Nesse sentido o governo uruguaio vem cumprindo sentença da $\mathrm{CIDH}$, que o condenou a reconhecer a responsabilidade do Estado no desaparecimento dos pais de Macarena Gelman. ${ }^{17}$ Considerando ser o Estado brasileiro um Estado Democrático, não pode

\footnotetext{
${ }^{17}$ Em março de 2012 o presidente do Uruguai, José Mujica, juntamente com o presidente da Suprema Corte de Justiça e dos comandantes da Marinha, do Exército e da Aeronáutica, organizaram um ato público no qual reconheceram a participação do Uruguai no desaparecimento de María Claudia de Gelman, sequestrada em setembro de 1976 na Argentina. Esse caso macabro envolve María Claudia que estava grávida de sete meses e foi levada para o centro de tortura da Operação Condor em Buenos Aires, a oficina mecânica conhe-
} 
ele compactuar ou se recusar a cumprir sentenças que exijam o respeito aos direitos humanos, porque, obviamente, não se trata somente do direito de uma e outra pessoa, isto afeta um direito maior que vem sendo violado, e a democracia não pode ser só institucional, é necessário que ela o seja de fato, na totalidade de seu funcionamento.

Focaremos agora nas possibilidades de superação desse problema, tendo em vista a necessidade de discutir práticas que assegurem a instituição pelo Estado das decisões da Corte Interamericana de Direitos Humanos.

- Política de Estado: A par disso, a primeira consideração a ser feita é que a proteção dos direitos humanos precisa se converter em uma política de Estado, para que, por meio do reconhecimento da responsabilidade internacional seja possível o fortalecimento do sistema, o que pode ocorrer pela busca comum da verdade dos fatos. Esse é o primeiro passo para mudar esse cenário, pois só a tomada de consciência por meio dessa responsabilidade é o que possibilitará um engajamento em prol de uma vontade política comprometida com a proteção dos direitos humanos.

- Cooperação entre os Estados: O que se depreende diante disso tudo é que as sentenças da CIDH possuem, em geral, o caráter obrigatório, mas não executório, gerando um grande problema quanto à eficácia das sentenças internacionais, perpassando pela ideia de que o êxito das execuções das sentenças internacionais não somente depende dos procedimentos processuais internacionais, mas também está condicionado à cooperação dos Estados-partes, por meio de um efetivo diálogo entre o sistema processual internacional e o sistema processual interno. Evi-

cida como Automotores Orletti. Desse local foi trasladada até Montevidéu, onde foi vista pela última vez em 1976, tendo sua filha recém-nascida, Macarena Gelman, entregue a um ex-policial uruguaio. 
dentemente que a Corte Interamericana enquanto órgão jurisdicional internacional não se isola do Direito de cada Estado, pois não se pode pensar sobre a execução das sentenças sem a cooperação dos próprios Estados.

- Instituição da sentença pelo poder Judiciário: Na concepção de Damián, um dos meios indiscutivelmente hábeis para garantir o cumprimento das sentenças proferidas pela Corte Interamericana reside no reconhecimento do caráter obrigatório das decisões por parte do poder Judiciário dos Estados-membros que se comprometeram com o Sistema Interamericano de Direitos Humanos. Ocorre que no Brasil, o STF é bem consciente de seu papel de zelar pelo cumprimento dos tratados que o Brasil pactuou.

Se nos termos da Corte Interamericana, porém, quem tem de cumprir a sentença pelos atos da República Federativa do Brasil é a União, entendemos que uma possibilidade para modificar esse cenário é encarregar o poder Judiciário de cada país de executar a decisão da Corte, coercitivamente, sempre que o Estado-membro responsabilizado internacionalmente não cumprir a sentença ou atrasar injustificadamente o seu cumprimento.

A esse respeito é importante salientar os esforços significativos do Judiciário de outros países, como a Argentina e a Colômbia, os quais vêm aplicando automaticamente as decisões dos órgãos do Sistema Interamericano, demonstrando avanços reais para possibilitar o cumprimento da sentença, o que continua sendo um desafio para muitos países (Bernardes, 2011).

- Aumento de recursos e recursos adicionais: Para que o Sistema Interamericano de Direitos Humanos possa desempenhar de forma eficaz e plena as suas funções, precisa otimizar os recursos que possui, por 
meio da promoção de um aumento substancial dos recursos destinados à Comissão e Corte Interamericana, e contar com recursos financeiros adicionais. Assim sendo,

si la OEA no está en capacidad de financiar adecuadamente el sistema interamericano de protección, los órganos que lo integran deben conseguir los fondos adicionales que necesitan a través de proyectos que se presenten a los organismos internacionales de financiamiento. Para esto sería necesario la elaboración de un plan estratégico conjunto en el cual se le explique a las distintas agencias donantes hacia dónde se quiere ir, cómo se quiere llegar y cuáles son los recursos que se van a necesitar, ante lo cual es necesaria la unidad, la cooperación y la buena voluntad de los distintos órganos del sistema (Cançado Trindade; Robles, 2004, p.140).

Essa sugestão representa o impulso inicial para uma mudança, que necessita ser, imediatamente, posta em prática, haja vista que hoje apenas $6 \%$ do orçamento da OEA são destinados para o Sistema Interamericano, e as melhoras nesse sentido devem ser levadas a sério a fim de promover melhores investimentos materiais e de recursos humanos.

- Medidas legislativas: Por conseguinte, a partir das afirmações feitas, é perceptível que os órgãos políticos possuem um papel inestimável como garantidores do funcionamento do Sistema, em especial no cumprimento das decisões da Corte Interamericana de Direitos Humanos, fazendo-se necessário, portanto, que sejam adotadas medidas legislativas que sejam necessárias para cumprir as sentenças emitidas pela Corte. A exemplo, cite-se o caso do Peru, que editou a Lei 27.775 de 5 de julho de 2002, disciplinando a sentença internacional, medidas de urgência, entre outras coisas, tornando mais direta e simples a execução, sem necessidade de homologação, do que aquela realizada nos casos das sentenças nacionais (Pereira, 2009). 
- Boa-fé objetiva e seus deveres anexos: Tudo isso deve estar aliado ao princípio da boa-fé, no qual o Brasil deve se pautar, realizando os melhores engajamentos possíveis para aplicar in concreto as sentenças, entre os quais o dever de diligência e à tríplice obrigação do Estado em prevenir, investigar e punir, evitando a impunidade. Esse desafio deve ser perquirido pelo poder Executivo, poder Judiciário e Ministério Público, sendo realizado por todos os meios legais em Direito permitidos, dirigido ao estabelecimento da verdade e punição dos responsáveis.

É importante salientar que até o presente momento o cumprimento das sentenças ocorreu de forma espontânea, demonstrando a boa-fé e lealdade processual do Brasil, de forma que entendemos que a boa-fé e a lealdade processual devem se estender para os fatores em que ainda há dificuldade na sua concretização, tal como a punição dos responsáveis.

O dever de informação encontra-se insculpido no artigo $5 \square$, inciso XIV da Constituição Federal de 1988, possuindo especial relevância no que diz respeito à efetivação das sentenças da Corte, pois, mediante a publicização das sentenças prolatadas por meio de qualquer sistema informativo o povo brasileiro ficará ciente e poderá exercer seu papel de cidadão, assim como é algo essencial para a supervisão do cumprimento das sentenças.

- Influência midiática: Se é verdade que a mídia exerce um importante papel na disseminação de informações, também é essencial o seu papel para pressionar os órgãos responsáveis pelo cumprimento das sentenças que violem os direitos humanos, pois Estado nenhum simpatiza com a ideia de ficar malvisto no cenário internacional. Ou seja, os direitos humanos, como já referido ao longo deste trabalho, surgem das lutas, e a postura da mídia a favor de uma pressão em cima de situações aterradoras envolvendo os direitos humanos, representa, em nossa opinião, uma forma de exigir uma mudança radical a fim de que as coisas não permaneçam do mesmo jeito que estão. 
Em nosso entendimento, a mídia pode ser utilizada como uma grande aliada na busca pela superação desse problema, pois representa uma instância de poder, que pode construir uma nova forma de influenciar os rumos da sociedade, e, assim sendo, daqueles que detêm o poder e que possuem condições concretas de promover mudanças que reflitam no contexto político-social.

- Políticas públicas promovidas pelo Estado: Em diversos casos, as sentenças prolatadas pela Corte abrangem uma infinidade de reparações a serem concretizadas pelos Estados. Essas medidas, em geral, envolvem não somente reparação econômica monetária, como também prestações a serem efetivadas por meio da instituição de políticas públicas, o que envolve um orçamento adequado para esta finalidade. Diante disso, é necessário a concretização de políticas públicas que visem ao resguardo da dignidade da pessoa humana e dos direitos humanos, tal como a que foi realizada, após sentença da Corte, exigindo que o Estado promovesse a instrução de funcionários que trabalham com pessoas com transtorno mental, no caso Ximenes.

- Analogia, costumes e princípios gerais de Direito: Tais princípios devem ser observados, sendo perfeitamente aplicáveis à efetivação da sentença nos casos em que houver dúvida sobre qual a legislação nacional a ser aplicada. Entendemos que nesses casos, a legislação adequada será aquela que melhor atender aos princípios que permeiam os direitos humanos (Coelho, 2008).

- Medidas provisórias: Observando-se a necessidade, muitas vezes, de garantir proteção às vítimas e familiares durante o transcurso do processo, faz-se imprescindível o uso de providências de urgência, que abrangem as medidas provisórias e cautelares. Nesse sentido, é interessante a antecipação do uso dessas medidas à Comissão, no caso de medidas provisórias, assim como a aceitação dos Estados no que se refere à imposição de adoção de medidas cautelares quando a Comissão 
entender necessário, a fim de resguardar um direito inerente à pessoa. Salienta-se que tal mecanismo já vem sendo utilizado pela Corte, e entendemos que nada impede que também seja aplicado o nosso ordenamento processual pátrio no que diz respeito às medidas de urgência, por estarem em consonância com os valores a serem assegurados pela Corte (González, 2010).

Por meio da Lei 27.775 surgida como medida legislativa para o cumprimento da sentença internacional, o Peru estipulou sobre as medidas provisórias (cautelar e antecipação de tutela), tendo 24 horas para o seu cumprimento (Pereira, 2009).

- Ampliação das medidas executivas propostas pela Convenção Interamericana de Direitos: Tendo em vista que os mecanismos executivos da Convenção Interamericana de Direitos não promovem uma eficácia interna plena, é necessário que os Estados-Membros ampliem as medidas para além daquelas apresentadas pela Convenção, tal como o Peru acabou fazendo, tornando a concretização das sentenças muito mais rápida.

- Modelo Distributivo para o Poder Judiciário: primar por um modelo distributivo para o Poder Judiciário representa mudar a concepção predominante de uma Justiça corretiva para uma Justiça proporcional, que permita alcançar uma Justiça mais rápida, condenando a pagar algo mais, levando em consideração, além dos fatos e coisas objeto do litígio, os fatores pessoais, o que implica agravar ou minorar a condenação. Ex.: capacidade financeira, bens, etc.

A esse respeito o juiz Roberto de Figueiredo Caldas, na sentença da Corte Interamericana de Direitos Humanos no caso Garibaldi vs Brasil, salientou a necessidade de um modelo distributivo para que os países que tenham problemas com a tramitação dos processos e impunidade possam se desenvolver. Do contrário, a morosidade processual continuará sendo um problema que a Corte continuará condenando (Caldas, 2009). 
- Controle de convencionalidade: Apesar de ser a doutrina jurisprudencial mais polêmica desenvolvida pela Corte Interamericana, é uma forma de ajudar a resolver uma parte das dificuldades enfrentadas na aplicação da sentença por parte dos juízes nacionais. A proposta que enseja a solução do problema envolve a classificação proposta por Néstor Pedro Saguiés e as considerações do juiz Ferrer MacGregor, cuja classificação leva em conta a intensidade, podendo ser forte ou fraca. Isto é, o controle de convencionalidade forte envolveria a obrigação do juiz nacional de deixar de aplicar uma norma interna por violar a Convenção Americana de Direitos Humanos. O controle de convencionalidade fraco refere-se à interpretação das normas internas de acordo com o disposto na Convenção Americana por parte da Corte (Contreras, 2012).

Assim sendo, diante de todas estas sugestões de soluções ao problema de cumprimento das sentenças da Corte, entendemos ser a de mais rápida aplicação a que poderá atribuir ao poder Judiciário o dever de cumprir tais sentenças no silêncio do Executivo.

\section{CONCLUSÃO}

Como foi referido até agora, o Brasil ainda tem muito o que melhorar em matéria de defesa dos direitos humanos. A aplicação correta dos dispositivos constitucionais, assim como o de tratados do qual somos signatários, torna-se uma tarefa mais que essencial na busca de uma igualdade e respeito a todos os seres humanos.

Assim, diante da evidente violação da dignidade da pessoa, parece-nos irrefutável concordar com as manifestações de Ingo Wolfgang Sarlet:

Lamentavelmente, cada vez mais a dignidade da pessoa humana é desconsiderada, desrespeitada, violada e desprotegida, seja pelo incremento assustador da violência contra a pessoa, seja pela carência 
social, econômica e cultural e grave comprometimento das condições existenciais mínimas para uma vida com dignidade e, neste passo, de uma existência com sabor de humanidade (2004, p. 126).

O poder Judiciário não se encontra sozinho diante da tarefa de cumprir e permear uma cultura em prol dos direitos humanos, pois o Executivo, o Legislativo e a própria sociedade devem reconhecer a sua parcela de responsabilidade e contribuição para que, por meio da convergência desses diversos atores sociais, continue sendo percorrido um caminho que, construído no cotidiano, possibilite a eficácia das sentenças de direitos humanos.

A sentença jamais será somente um ato processual que satisfaz o interesse da parte, muito pelo contrário, sempre irá refletir reivindicações históricas e culturais do povo e de todos aqueles que foram afetados, de uma forma ou de outra, pelo motivo central que impulsionou a exigência de uma prestação jurisdicional por parte do Estado.

A falta de eficácia das decisões da Corte poderá levar ao "fim dos direitos humanos" (Douzinas, 2009), no sentido da sua extinção, sendo necessário ir além do mero discurso que alimenta as grandes potências, para que o Sistema Interamericano, enquanto instância capaz de fiscalizar o cumprimento das sentenças, continue sendo preservado, promovendo o fortalecimento do Estado de Direito.

A pesquisa sobre a eficácia das sentenças da Corte Interamericana é um tema inquietante, intrigante e por tal razão nos mobilizou a pesquisar com entusiasmo. Isto a fim de apresentarmos nossas conclusões e sugestões à comunidade científica, o que ora fazemos, com uma única finalidade: despertar o questionamento de consciências sobre a importância de encontrarmos mecanismos eficazes para o cumprimento das sentenças da Corte Interamericana, na presente revista, que por sua envergadura dá visibilidade aos preciosos temas aqui tratados. 
Esta infindável busca pelo cumprimento das sentenças pela Corte diz respeito à segurança quanto ao futuro da democracia em nosso continente (em muitos lugares os direitos humanos ainda estão na fase préhistórica), e também com a evolução dos próprios direitos humanos (no tempo e no espaço), que deve se aperfeiçoar e assegure-se, então, o cumprimento das sentenças.

Tal assertiva não é um sonho. É uma necessidade, a fim de que sejam garantidas às futuras gerações a paz, a tranquilidade e a dignidade de todas as pessoas.

Por todo o exposto, o não cumprimento das sentenças da Corte é o extremo do desrespeito não somente à Corte, mas sobretudo a negação dos direitos humanos, não somente no âmbito das instituições, mas diante das pessoas e entre elas, estimulando a barbárie e o retrocesso social. Se as instituições não assumem uma postura no sentido de efetivar os direitos humanos, o que restará para as pessoas?

Só as lutas são capazes de promover mudanças concretas na sociedade e a prova maior disso se encontra no nosso cotidiano, com as mudanças existentes no decorrer da longa trajetória do homem até os dias de hoje. Se olharmos para trás, provavelmente irá demorar um pouco para acreditarmos que tantas transições ocorreram para melhor, contribuindo significativamente para a construção de um mundo mais próspero, que coloque a dignidade humana como pilar essencial de um Estado que deve estar a serviço da comunidade.

Todo ser humano é sujeito de direitos, e não há melhor ocasião que esta para ressaltar que os Estados-partes precisam estar comprometidos com a eficácia das sentenças, resgate este que não tem força apenas nos dispositivos constitucionais, mas também na mudança para uma cultura da solidariedade que coloque o indivíduo, antes e acima de tudo, com o objetivo de realização efetiva dos direitos humanos, garantidos na CF/88 e nos diversos tratados internacionais dos quais o Brasil é signatário. 


\section{REFERÊNCIAS}

ACCIOLY, Hildebrando; DO NASCIMENTO E SILVA, G. E.; CASELLA, Paulo Borba. Manual de Direito Internacional Público. 19. ed. São Paulo: Saraiva, 2011.

AMBOS, Kai; MALARINO, Ezequiel; ELSNER, Gisela. Cooperación y Asistencia Judiciaria con La Corte Penal Internacional: Contribuciones de America Latina, Alemaña, España y Italia. Montevideo: Konrad Adenauer Stiftung, 2007.

BARRETTO, Vicente de Paulo. Direitos Humanos, Democracia e Globalização. In: STRECK, Lenio Luiz; BARRETTO, Vicente de Paulo; CULLETTON, Alfredo Santiago (Org.). 20 anos de Constituição - Os Direitos Humanos entre a norma e a política. São Leopoldo: Oikos, 2009.

BARROSO, Luís Roberto. Judicialização, ativismo judicial e legitimidade democrática. Revista de Direito do Estado, Rio de Janeiro: Editora Renovar, 2009.

BERNARDES, Marcia Nina. Sistema Interamericano de Direitos Humanos como esfera pública transnacional: aspectos jurídicos e políticos da implementação de decisões internacionais. São Paulo: Sur - Rede Universitária de Direitos Humanos, 2011.

BOBBIO, Norberto. A era dos Direitos. Tradução Nelson Coutinho. Rio de Janeiro: Campus, 1992.

CALDAS, Roberto de Figueiredo. Voto fundamentado na sentença da Corte no caso Garibaldi vs Brasil: por um modelo distributivo para o Poder Judiciário. In: Corte Interamericana de Direitos Humanos. 2009. Disponível em: <http:// www.corteidh.or.cr/docs/casos/articulos/seriec_203_por.pdf>. Acesso em: ago. 2012.

CANÇADO TRINDADE, Antônio Augusto; ROBLES, Manuel Ventura. El futuro de la Corte Interamericana de Derechos Humanos. San José da Costa Rica: Corte Interamericana de Derechos Humanos, 2004.

CARBONARI, Paulo César (Org.). Sentido Filosófico dos Direitos Humanos: leituras do pensamento contemporâneo. Passo Fundo: Ifibe, 2006. 
COELHO, Rodrigo Meirelles Gaspar. Direitos humanos na OEA e a busca pela eficácia das sentenças da Corte Interamericana. 2008. Disponível em: <http:// jus.com.br/revista/texto/11519>. Acesso em: 13 ago. 2012.

COMPARATO, Fábio Konder. A afirmação histórica dos Direitos Humanos. 5. ed. São Paulo: Editora Saraiva, 2007.

CONTRERAS, Ana María Carmona. Introducción a la Ciencia Política. Sevilla: Universidad de Sevilla, 2012.

CONTRERAS, Pablo. Control de Convencionalidad Fuerte y Débil: Parte I. Chile: Diario Constitucional.cl. 2012. Disponível em: <http://diarioconstitucional.cl/mostrararticulo.php?id=188>.Acesso em: ago. 2012.

CORREIA, Theresa Rachel Couto. Corte Interamericana de Direitos Humanos: repercussão jurídica das opiniões consultivas. Curitiba: Juruá, 2008.

CULLETON, Alfredo; BRAGATO, Fernanda Frizzo; FAJARDO, Sinara Porto. Curso de Direitos Humanos. São Leopoldo: Editora Unisinos, 2009.

DOUZINAS, Costas. O fim dos Direitos Humanos. Tradução Luzia Araújo. São Leopoldo: Unisinos, 2009.

ENGELMANN, Wilson. A origem jusnaturalista dos Direitos Humanos: o horizonte histórico da Declaração Universal dos Direitos Humanos de 1948. Maringá: Conpedi, 2009. Disponível em: <http://www.conpedi.org.br/manaus/ arquivos/anais/maringa/Maringa_integra.pdf $>$. Acesso em: 13 ago. 2012.

FRAGA, Mirtô. O conflito entre tratado internacional e norma de direito interno. Estudo analítico da situação do tratado na ordem jurídica brasileira. Rio de Janeiro: Editora Forense, 1998.

GONZÁLEZ, Felipe. As medidas de urgência no sistema interamericano de Direitos Humanos. São Paulo: Sur - Rede Universitária de Direitos Humanos, 2010.

GONZÁLEZ-SALZBERG, Damián. A implementação das sentenças da Corte Interamericana de Direitos Humanos na Argentina: uma análise do vaivém jurisprudencial da Corte Suprema de Justiça da Nação. São Paulo: Sur - Rede Universitária de Direitos Humanos, 2011. 
GREGORI, Maria Filomena. Cenas e queixas. Um estudo sobre mulheres, relações violentas e a prática feminista. Rio de Janeiro: Editora Paz e Terra, 1993.

HERMANN, Jacqueline; BARSTED, Leila Linhares (Orgs.). Instrumentos internacionais de proteção aos direitos humanos. Rio de Janeiro: Cepia, 2001.

HEYNS, Christof; PADILLA, David; ZWAAK, Leo. Comparação esquemática dos sistemas regionais de Direitos Humanos: uma atualização. São Paulo: Sur - Rede Universitária de Direitos Humanos, 2006.

ISSAEVA, Maria; SERGEEVA, Irina; SUCHKOVA, Maria. Execução das decisões da Corte Europeia de Direitos Humanos na Rússia: avanços recentes e desafios atuais. Revista Internacional de Direitos Humanos. São Paulo: Sur Rede Universitária de Direitos Humanos, 2011.

JAYME, Fernando G. Direitos humanos e sua efetivação pela Corte Interamericana de Direitos Humanos. Belo Horizonte: Del Rey, 2005.

LAYA, Ana et al. A eficácia do Sistema Interamericano de Proteção de Direitos Humanos: uma abordagem quantitativa sobre seu funcionamento e sobre o cumprimento de suas decisões. Revista Internacional de Direitos Humanos, São Paulo: Sur - Rede Universitária de Direitos Humanos, v. 7, n. 12, p. 9-35, jun. 2010.

LLORENS, Jorge Cardona. La función contenciosa de La Corte Interamericana de Derechos Humanos. In: CORTE INTERAMERICANA DE DERECHOS HUMANOS. El sistema interamericano de protección de los derechos humanos en el umbral del siglo XXI. San José: Corte IDH, 2001.

MEDINA, Damares. 2008. Amigo da Corte ou amigo da parte? Amicus Curiae no Supremo Tribunal Federal. 2008. Disponível em: <http://oab-ma.jusbrasil.com.br/noticias/340675/amicus-curiae-influi-em-decisoes-do-stf-mostrapesquisa>. Acesso em: 12 jun. 2012.

MOTT, Luiz. Número de assassinatos de homossexuais bate recorde. Correio do Estado. Disponível em: <http://www.correiodoestado.com.br/noticias/ numero-de-assassinatos-de-homossexuais-bate-recorde-no-pais_4>. Acesso em: 10 jun. 2012. 
MÜLLER, Friedrich. Quem é o povo? A questão fundamental da democracia. Rio de Janeiro: Revista dos Tribunais, 2010.

NERBA, Graziela C.; GROSSI, Patrícia Krieger. Violências e gênero. Coisas que a gente não gostaria de saber. Porto Alegre: Editora EDIPUCRS, 2001.

PAGE, Henri de. Traité élementaire de droit civile Belge. 1933, t. I, cap. III. Ob. cit. In: TEIXEIRA, Sálvio de Figueiredo. O juiz: seleção e formação do magistrado no mundo contemporâneo. Belo Horizonte: Del Rey, 1999.

PEREIRA, Marcela Harumi Takahashi. Cumprimento da sentença da Corte Interamericana de Direitos Humanos no âmbito interno. 2009. Disponível em: <http://www.ambito-juridico.com.br/site/?n_link=revista_artigos_ leitura\&artigo_id=6491\&revista_caderno=16>. Acesso em: 10 ago. 2012.

PIOVESAN, Flávia. Direitos Humanos e o Direito Constitucional Internacional. Prefácio Henry Steiner. Apresentação Antônio Augusto Cançado Trindade. 8. ed. revista, ampliada e atualizada. São Paulo: Saraiva, 2007.

PITANGUY, Jacqueline. O STF e os direitos humanos das mulheres. Jornal O Dia. Maio 2012. Acesso em: 29 abr. 2012. p. 1.

RESCIA, Victor Manoel Rodrigues. Eficácia jurídica de la Jurisprudencia de La Corte Interamericana de Derechos Humanos. In: NAVIA NIETO, Rafael. La corte y el Sistema Interamericano de Derechos Humanos. San José: Corte Interamericana de Derechos Humanos, 1994.

RIBEIRO, Darci Guimarães; SCALABRIN, Felipe. O papel do processo na construção da democracia: para uma nova definição da democracia participativa. Revista de Direito Processual, Belo Horizonte: Editora Fórum, v. 17, n. 65, p. 53-68, 2009.

ROSATO, Cássia Maria; CORREIA, Ludmila Cerqueira. Caso Damião Ximenes Lopes: mudanças e desafios após a primeira condenação do Brasil pela Corte Interamericana de Direitos Humanos. Revista Internacional de Direitos Humanos, São Paulo: Sur - Rede Universitária de Direitos Humanos, v. 8, n. 15, p. 93-113, dez. 2011. 
SACCHETTA, Paula. Brasil descumpre sentença da Corte Interamericana sobre mortos da guerrilha. Revista Adusp, Associação dos Docentes da USP, Seção Sindical da Andes-SN, Adusp, n. 52, p. 60-65, abr. 2012.

SANTOS, Luiz Wanderley dos. A eficácia das Normas Constitucionais. Boletim Jurídico, Uberaba/MG, a. 1, n. 1. Disponível em: <http://www.boletimjuridico. com.br/ doutrina/texto.asp?id=107> Acesso em: 17 jul. 2012.

SARLET, Ingo Wolfgang. Dignidade da pessoa humana e direitos fundamentais na Constituição Federal de 1988. Porto Alegre: Livraria do Advogado, 2004.

STEIN, Ernildo. Introdução ao Método Fenomenológico Heideggeriano. In: Sobre a essência do fundamento. Conferências e Escritos Filosóficos de Martin Heidegger. Tradução Ernildo Stein. São Paulo: Editora Abril Cultural, 1979. (Coleção Os Pensadores).

VENTURA, Deisy; PIOVESAN, Flávia; KWEITEL, Juana. Sistema interamericano sob forte ataque. In: <http://www1.folha.uol.com.br/fsp/opiniao/59213sistema-interamericano-sob-forte-ataque.shtml>. Acesso em: 7 ago. 2012. VIOLA, Solon Eduardo Annes. Direitos Humanos e Democracia no Brasil. São Leopoldo: Editora Unisinos, 2008.

\section{Sites consultados}

<http://sul21.com.br/jornal/2012/03/\%E2\%80\%9Cqueremosjustica\%E2\%80\%9D-cobra-victoria-grabois->

$<$ http://www.correiodoestado.com.br/noticias/numero-de-assassinatos-dehomossexuais-bate-recorde->.

$<$ http://cidh.oas.org/Comunicados/Port/2012.89.htm>.

$<$ http://oab-ma.jusbrasil.com.br/noticias/340675/amicus-curiae-influi-emdecisoes-do-stf-mostra-pesquisa>.

<http://www.observe.ufba.br/lei_mariadapenha>

$<$ http://www.oabgo.org.br/oab/noticias/judiciario/12-03-2012-abarrotado-deprocessos-stj-busca-filtros->. 
$<\mathrm{http}$ ://www.direitos.org.br/index.php?option=com_content\&task=view\&id $=2195 \&$ Itemid $=2>$.

$<\mathrm{http}: / /$ www.violenciamulher.org.br/>.

$<$ http://www.mndh.org.br/index.php?option=com_content\&task=view\&id= $2797 \&$ Itemid $=45>$.

<http://www.stf.jus.br/portal/cms/verNoticiaDetalhe. asp?idConteudo $=100474>$.

Recebido em 31/3/2013

Aprovado em 11/4/2013 